Supplementary Information

\title{
Manipulating Redox Kinetics of Sulfur Species Using Mott-Schottky Electrocatalysts for Advanced Lithium-Sulfur Batteries
}

Yuanjian Li ${ }^{a}$, Wenyu Wang a , Bao Zhang ${ }^{b \ddagger}$, Lin Fu ${ }^{a}$, Mintao Wan ${ }^{\text {a }}$, Guocheng $\mathrm{Li}^{\text {a }}$, Zhao Cai ${ }^{\text {a }}$, Shuibin Tu ${ }^{\text {a }}$, Xiangrui Duan ${ }^{\text {a }}$, Zhi Wei Seh ${ }^{\mathrm{c}}$, Jianjun Jiang ${ }^{\mathrm{b}}$, Yongming $\operatorname{Sun}^{\mathrm{a} *}$

a Wuhan National Laboratory for Optoelectronics, Huazhong University of Science and Technology, Wuhan 430074, China

${ }^{\mathrm{b}}$ School of Optical and Electronic information, Huazhong University of Science and Technology, Wuhan 430074, China

${ }^{\mathrm{c}}$ Institute of Materials Research and Engineering, Agency for Science, Technology and Research ( * $^{*}$ STAR), Innovis 138634, Singapore.

$\$$ These authors contributed equally to this work

*To whom correspondence should be addressed. Email:yongmingsun@hust.edu.cn 


\section{Experimental Section}

Materials: Cobalt (II) nitrate hexahydrate $\left(\mathrm{Co}\left(\mathrm{NO}_{3}\right)_{2} \cdot 6 \mathrm{H}_{2} \mathrm{O}\right)$, zinc(II) nitrate hexahydrate $\left(\mathrm{Zn}\left(\mathrm{NO}_{3}\right)_{2} \cdot 6 \mathrm{H}_{2} \mathrm{O}\right)$, and hydrochloric acid $(\mathrm{HCl})$ were bought from Sinopharm Chemical Reagent limited corporation. Sublimed sulfur (S) was purchased from Aladdin. 2-methylimidazole (2-mlm) and lithium sulfide $\left(\mathrm{Li}_{2} \mathrm{~S}\right)$ was obtained from Sigma-Aldrich. All chemicals and solvents were used without purification.

Synthesis of CoZn-ZIF: CoZn-ZIF precursor was synthesized according to previous reports. ${ }^{[1]}$ In a typical synthesis, $\mathrm{Co}\left(\mathrm{NO}_{3}\right)_{2} \cdot 6 \mathrm{H}_{2} \mathrm{O}(1.455 \mathrm{~g}, 5 \mathrm{mmol})$ and $\mathrm{Zn}\left(\mathrm{NO}_{3}\right)_{2} \cdot 6 \mathrm{H}_{2} \mathrm{O}(1.487 \mathrm{~g}, 5 \mathrm{mmol})$ were dissolved in $80 \mathrm{~mL}$ of deionized (DI) water. In a separate container, $3.284 \mathrm{~g}$ (40 mmol) 2-mlm was dissolved in $80 \mathrm{~mL}$ of DI water. Then, the two solutions were quickly mixed and vigorously stirred for $4 \mathrm{~h}$ at $25^{\circ} \mathrm{C}$. After that, the precipitates were collected by centrifugation and thoroughly washed with DI water and absolute ethanol for 3 times. Finally, the CoZn-ZIF products were dried at $80{ }^{\circ} \mathrm{C}$ in vacuum.

Synthesis of Co@NC heterostructure: The prepared CoZn-ZIF powders were carbonized at $800{ }^{\circ} \mathrm{C}$ with a heating rate of $2{ }^{\circ} \mathrm{C} \mathrm{min}{ }^{-1}$ for $2 \mathrm{~h}$ under $\mathrm{Ar} / \mathrm{H}_{2}(5 \%)$ atmosphere in a tube furnace. After cooling, the pyrolyzed products were washed with $0.1 \mathrm{M} \mathrm{HCl}$ solution to remove unstable metal species to obtain the Co@NC catalysts.

Synthesis of NC catalysts: The monometallic Zn-ZIF precursor was obtained by dissolving $2.974 \mathrm{~g} \mathrm{Zn}\left(\mathrm{NO}_{3}\right)_{2} \cdot 6 \mathrm{H}_{2} \mathrm{O}$ and $3.284 \mathrm{~g} \mathrm{2-mlm}$ in $80 \mathrm{~mL}$ of DI water, respectively, and after the same process with CoZn-ZIF precursor. After pyrolysis of Zn-ZIF precursors under the same conditions as CoZn-ZIF precursor, NC catalysts could be obtained.

Synthesis of Co catalysts: The monometallic Co-ZIF was were obtained by dissolving $2.974 \mathrm{~g} \mathrm{Zn}\left(\mathrm{NO}_{3}\right)_{2} \cdot 6 \mathrm{H}_{2} \mathrm{O}$ and $3.284 \mathrm{~g}$ 2-mlm in $80 \mathrm{~mL}$ of (DI) water, respectively, and 
after the same process with CoZn-ZIF precursor. The obtained Co-ZIF precursors were then calcined in air at $300{ }^{\circ} \mathrm{C}$ for $2 \mathrm{~h}$ and then $\mathrm{Ar} / \mathrm{H} 2(5 \%)$ atmosphere at $300{ }^{\circ} \mathrm{C}$ for 2 $\mathrm{h}$ to obtain the sample of Co metal.

Synthesis of Co/NC composite: The Co and NC composite (denoted as $\mathrm{Co} / \mathrm{NC}$ ) was prepared by physically mixing Co metal and NC materials with a mass ratio of 11.6: 88.4 .

Synthesis of sulfur hybrid composites: The prepared $\mathrm{Co} @ \mathrm{NC}, \mathrm{NC}, \mathrm{Co}$, and $\mathrm{Co} / \mathrm{NC}$ materials were mixed with sulfur powder thoroughly in the mass ratio of 1:3, respectively. The mixture was sealed in a container, and treated at $155^{\circ} \mathrm{C}$ for 24 hours, and then at $200{ }^{\circ} \mathrm{C}$ for $2 \mathrm{~h}$ under an inert atmosphere. Finally, $\mathrm{Co} @ \mathrm{NC} / \mathrm{S}, \mathrm{NC} / \mathrm{S}, \mathrm{Co} / \mathrm{S}$, and $\mathrm{Co} / \mathrm{NC} / \mathrm{S}$ composites were obtained.

Materials Characterization: Scanning electron microscope (SEM, ZEISS, GeminiSEM300) and high-resolution transmission electron microscopy (HRTEM, FEI Talos F200X) with energy dispersive spectroscopy (Oxford instruments) were used to characterize the morphology. Powder X-ray powder diffraction (XRD, PANalytical B.V. Empyrean) with $\mathrm{Cu} \mathrm{K} \alpha$ radiation $(\lambda=1.5418 \AA)$ was employed to confirm the crystal structure. X-ray photoelectron spectroscopy was performed on AXIS-ULTRA DLD-600W (Kratos) using a monochromatic Al Ka X-ray source. Ultraviolet Photoelectron Spectroscopy (UPS) was collected on PHI5000 VersaProbe III (Scanning ESCA Microprobe) equipped with ultraviolet photoelectron spectroscopy (Hel $(21.2 \mathrm{eV})$ ). Raman spectroscopy was obtained with a confocal Raman spectrometer (LabRAM HR800, Horiba JobinYvon) using a $532 \mathrm{~nm}$ excitation laser. N2 adsorption-desorption isotherms were carried out using an ASAP 2460 apparatus (Micromeritics), where the specific surface area was determined by the BrunauerEmmett-Teller (BET) method. Thermogravimetry (TGA) was performed on Pyris1 TGA (PerkinElmer Instruments). 
Preparation of $\mathrm{Li}_{2} \mathrm{~S}_{6}$ Solutions for Adsorption Test and XPS Analysis: $\mathrm{Li}_{2} \mathrm{~S}_{6}$ solution was prepared by mixing $\mathrm{Li}_{2} \mathrm{~S}$ and sulfur with a molar ratio of $1: 5$, and then dissolve into a mixture of DOL and DME (v/v=1:1) with 1 M LiTFSI stirred for various hours in an Ar-filled glovebox to fabricate the concentration of $0.5 \mathrm{M} \mathrm{Li}_{2} \mathrm{~S}_{6}$ solution. Then, $50 \mathrm{mg}$ of $\mathrm{Co} @ \mathrm{NC}$ or $\mathrm{NC}$ were added into $6 \mathrm{~mL} \mathrm{Li}_{2} \mathrm{~S}_{6}$ solution. The suspension was stirred for $5 \mathrm{mins}$ and rested for $12 \mathrm{~h}$ to monitor the adsorption behavior. After that, the Co@NC was collected and dried under vacuum overnight for XPS analysis.

Electrochemical Measurements of Symmetric Cell: The sulfur-free active material (Co@NC or NC) were first mixed with polyvinylidene fluoride (PVDF) in a weight ratio of 90:10 in N-methyl-2-pyrrolidone (NMP) to be spread onto aluminum foil substrate and be used as the catalyst electrode. Standard coin cells (2025) were assembled by employing catalyst electrode as the working and the counter electrode, a Celgard 2400 membrane as the separator, and $20 \mu \mathrm{L} 0.5 \mathrm{M} \mathrm{Li}_{2} \mathrm{~S}_{6}$ solution as the catholyte and $20 \mu \mathrm{L}$ of $1.0 \mathrm{M}$ LiTFSI in DOL/DME $(\mathrm{v} / \mathrm{v}=1: 1)$ solution as the electrolyte. The CV measurement of the symmetric cell was conducted at a scan rate of 2-100 $\mathrm{mV} \mathrm{s}^{-1}$ with a voltage window between -0.8 and $0.8 \mathrm{~V}$. The EIS measurement was conducted at open-circuit voltage the frequency ranges from $100 \mathrm{kHz}$ to $0.1 \mathrm{~Hz}$ with a sinusoidal voltage of an amplitude of $5 \mathrm{mV}$.

Electrochemical Measurements of Asymmetric Cell: Standard 2025 coin cell were assembled by employing the as-prepared catalysts electrodes as the cathodes, Celgard 2400 as the separator, lithium foils as the anodes, and $20 \mu \mathrm{L}$ of $0.5 \mathrm{M} \mathrm{Li}_{2} \mathrm{~S}_{6}$ solution as the catholyte, and $20 \mu \mathrm{L}$ of $1.0 \mathrm{M}$ LiTFSI in DOL/DME $(\mathrm{v} / \mathrm{v}=1: 1)$ solution as the electrolyte. For the Li2S nucleation tests, the cells were galvanostatically discharged at $50 \mathrm{~mA} \mathrm{~g}-1$ from the open circuit condition to $2.0 \mathrm{~V}$. For the $\mathrm{Li}_{2} \mathrm{~S}$ dissolution process, the cells were firstly discharged to $1.7 \mathrm{~V}$ for fully transforming $\mathrm{S}$ to solid $\mathrm{Li}_{2} \mathrm{~S}$. After this discharge, the cells were then potentiostatically charged at $2.40 \mathrm{~V}$ for the 
dissolution of $\mathrm{Li}_{2} \mathrm{~S}$ into LiPS until charge current was below 10-5 A.

Electrochemical Measurements of Li-S Cell: The electrochemical tests were conducted by assembling coin-type cells (2032) in an argon-filled glove box. The slurry was prepared by fully mixing 80 wt \% active materials $(\mathrm{Co} @ \mathrm{NC} / \mathrm{S}$ or NC/S), 10 wt \% Super P carbon, and $10 \mathrm{wt} \%$ PVDF in an appropriate amount of NMP via a planetary mixer (THINKY). Then, the slurry was pasted on a current collector (carbon coated aluminum foil), vacuum dried at $60{ }^{\circ} \mathrm{C}$ for $12 \mathrm{~h}$, and cut into a disk of $10 \mathrm{~mm}$ diameter. The regular sulfur loading of the cathode was $\sim 1.5 \mathrm{mg} \mathrm{cm}^{-2}$. The Co@NC/S cathode with high active mass loading of $6.11 \mathrm{mg} \mathrm{cm}^{-2}$ was also fabricated using polyacrylic acid (PAA) binder instead of PVDF binder. The sulfur electrode with higher active mass loading (10.73 $\mathrm{mg} \mathrm{cm}^{-2}$ ) was prepared using carbon paper current collector to replace the carbon coated aluminum foil. The lithium foil was employed as both reference and counter electrodes. The electrodes were separated by a Celgard 2400 separator. The electrolyte was lithium bis (trifluoromethanesulfonyl) imide (LiTFSI, $1.0 \mathrm{M})$ in 1, 3-dioxolane and 1, 2-dimethoxyethane (v/v=1:1) with $0.2 \mathrm{M} \mathrm{LiNO}_{3}$ as additive. The electrolyte usages are 30,40 , and $50 \mu \mathrm{L}$ for sulfur cathode with loading of $1.5,6.11$, and $10.73 \mathrm{mg} \mathrm{cm}^{-2}$, respectively. The electrochemical performance was tested on a Neware Battery Tester with a voltage window of 1.7-2.8 V. All the capacities of cells have been normalized based on the weight of sulfur. The cyclic voltammetry (CV) test was performed using a Biologic VMP-3 electrochemical workstation.

The Calculations of Activation Energy : The activation energy of the charging/ discharging process was calculated according to the slope of the Tafel plot and the following equation:[10]

$$
\mathrm{E}_{\mathrm{a}, \mathrm{Ox} / \mathrm{Red}}=E_{0 \mathrm{a}, \mathrm{Ox} / \mathrm{Red}}-\varphi_{\text {cathode }}(\mathrm{Ox} / \mathrm{Red})_{\mathrm{IR}} \mathrm{RT} / \mathrm{b}
$$

Where Ea,Red is the activation energy of the reduction process, E0a, Red is the intrinsic activation energy, $\mathrm{b}$ is the slope of Tafel plot, $\varphi$ cathode is the irreversible potential in the reduction process. 
Density Functional Theory (DFT) Methods: The DFT calculations ${ }^{[3,4]}$ are performed by using Vienna Ab-initio Simulation Package (VASP) ${ }^{[5]}$ with Projector Augmented Wave (PAW) method ${ }^{[6]}$. And the exchange-correlation energy is described by the functional of Perderw, Burke, and Ernzerhof (PBE) ${ }^{[7,8]}$ form including van der Waals corrections (DFT-D3 method) ${ }^{[9]}$. The kinetic energy cutoff of electron wave functions is $520 \mathrm{eV}$. A supercell of graphene containing $4 \times 4$ unit cells is used to model N-C and Co-NC systems. The geometry optimizations are performed by using the conjugated gradient method, and the convergence threshold is set to be $10^{-4} \mathrm{eV}$ in energy and 0.01 $\mathrm{eV} \AA^{-1}$ in force. A vacuum layer of $15 \AA$ is applied for all calculated models. The climbing-image nudged elastic band (CI-NEB) method ${ }^{[10]}$ is employed to evaluate the barriers for $\mathrm{Li}_{2} \mathrm{~S}$ decomposition.

For the catalytic mechanism calculations, following steps are under consideration:

$$
\begin{aligned}
& \mathrm{S}_{8}(\mathrm{~s})+2 \mathrm{Li}^{+}+2 e^{-} \rightarrow \mathrm{Li}_{2} \mathrm{~S}_{8}{ }^{*} \\
& 3 \mathrm{Li}_{2} \mathrm{~S}_{8}^{*}+2 \mathrm{Li}^{+}+2 e^{-} \rightarrow 4 \mathrm{Li}_{2} \mathrm{~S}_{6}^{*} \\
& 2 \mathrm{Li}_{2} \mathrm{~S}_{6}^{*}+2 \mathrm{Li}^{+}+2 e^{-} \rightarrow 3 \mathrm{Li}_{2} \mathrm{~S}_{4}^{*} \\
& \mathrm{Li}_{2} \mathrm{~S}_{4}^{*}+2 \mathrm{Li}^{+}+2 e^{-} \rightarrow 2 \mathrm{Li}_{2} \mathrm{~S}_{2}^{*} \\
& \mathrm{Li}_{2} \mathrm{~S}_{2}^{*}+2 \mathrm{Li}^{+}+2 e^{-} \rightarrow 2 \mathrm{Li}_{2} \mathrm{~S}^{*} \\
& \mathrm{Li}_{2} \mathrm{~S}^{*} \rightarrow \mathrm{Li}_{2} \mathrm{~S}(\mathrm{~s})
\end{aligned}
$$

And at potential of $0 \mathrm{~V}\left(\mathrm{vs} . \mathrm{Li} / \mathrm{Li}^{+}\right)$:

$$
\mathrm{Li}^{+}+e^{-} \rightarrow \operatorname{Li}(\mathrm{s}) \quad \Delta G=0
$$

Herein, the potential in reaction pathway is set as $2.0 \mathrm{~V}\left(\mathrm{vs} . \mathrm{Li} / \mathrm{Li}^{+}\right)$ 

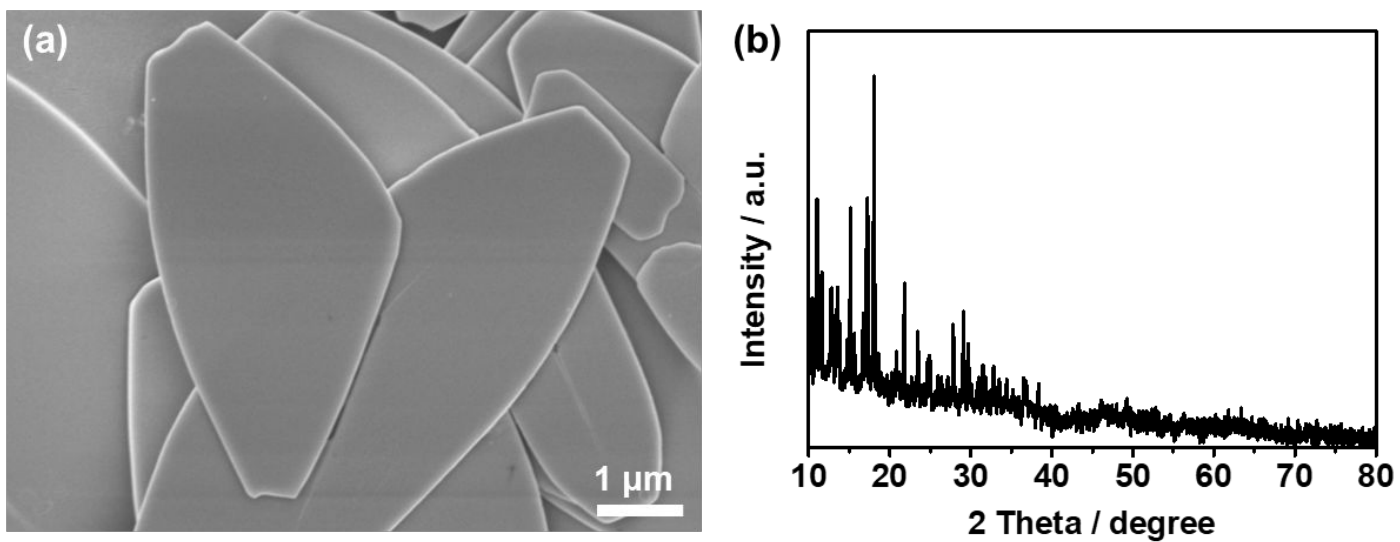

Figure S1. (a) SEM image and (b) XRD pattern of CoZn-ZIF precursor.

The SEM image and XRD pattern in Figure S1 reveal the leaf-shaped morphology and crystalline structure of CoZn ZIF precursor. ${ }^{[1]}$
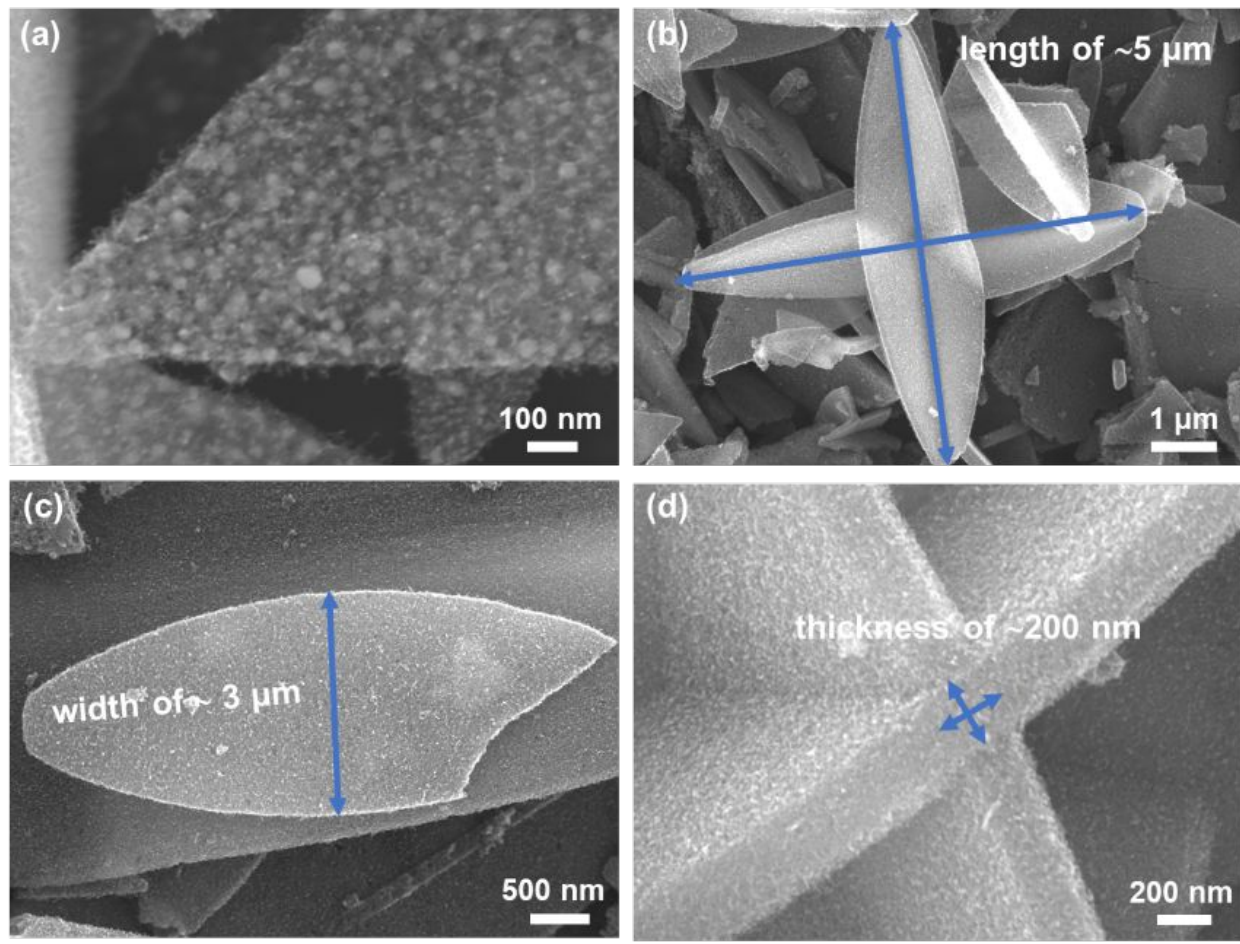

Figure S2. (a-d) additional SEM images of Co@NC materials. 


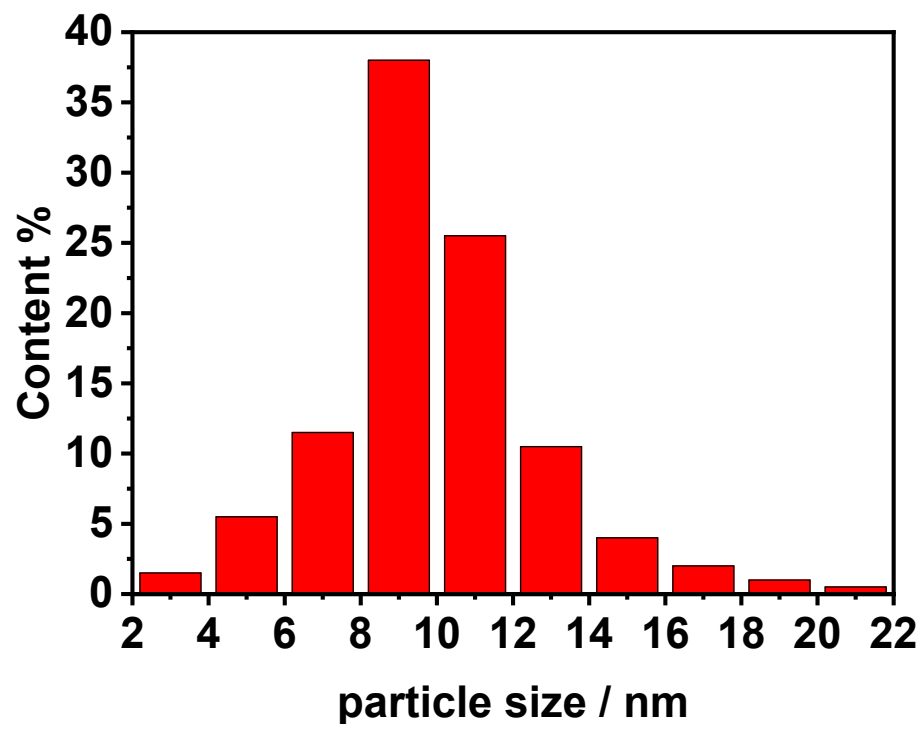

Figure S3. The size distribution of Co particles.

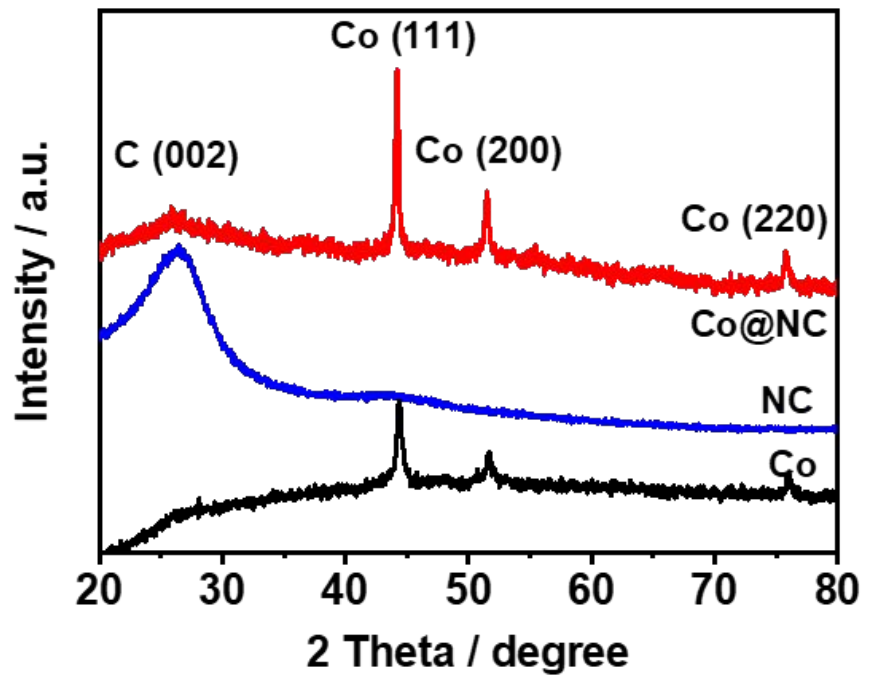

Figure S4. XRD patterns of Co, NC and Co@NC catalysts. 


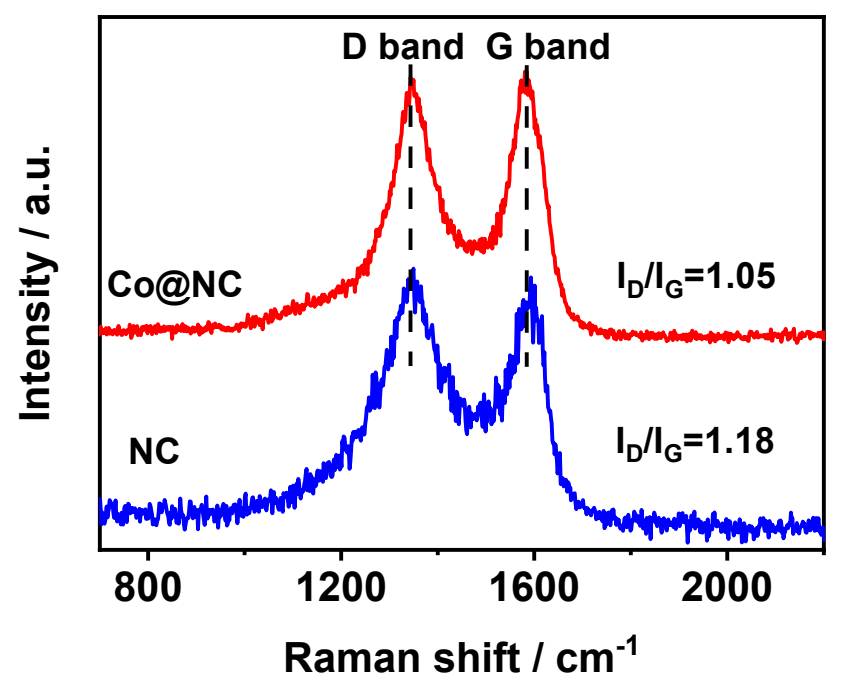

Figure S5. Raman spectra of NC and Co@NC.

(a)

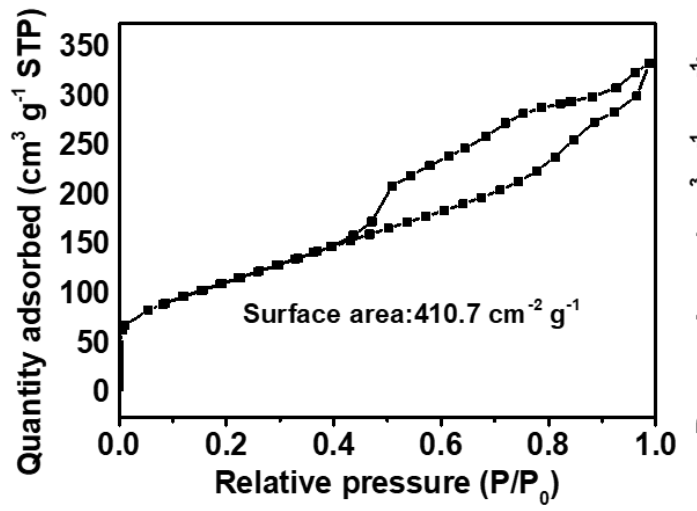

(b)

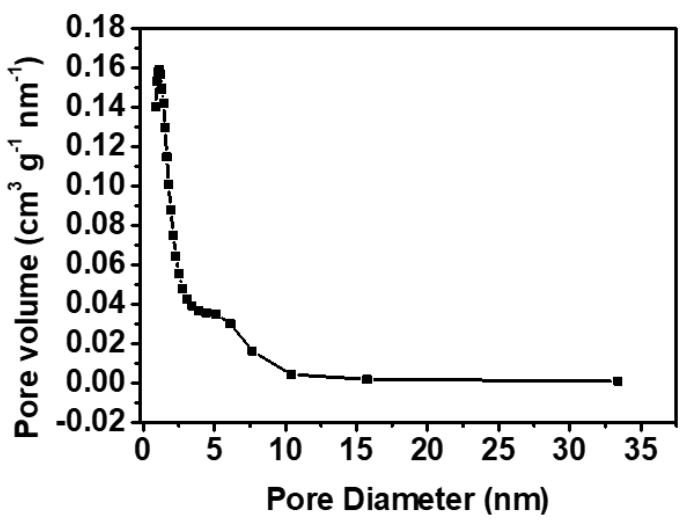

Figure S6. (a) $\mathrm{N}_{2}$ adsorption-desorption isotherms and (b) pore size distribution based on the BJH method of Co@NC.

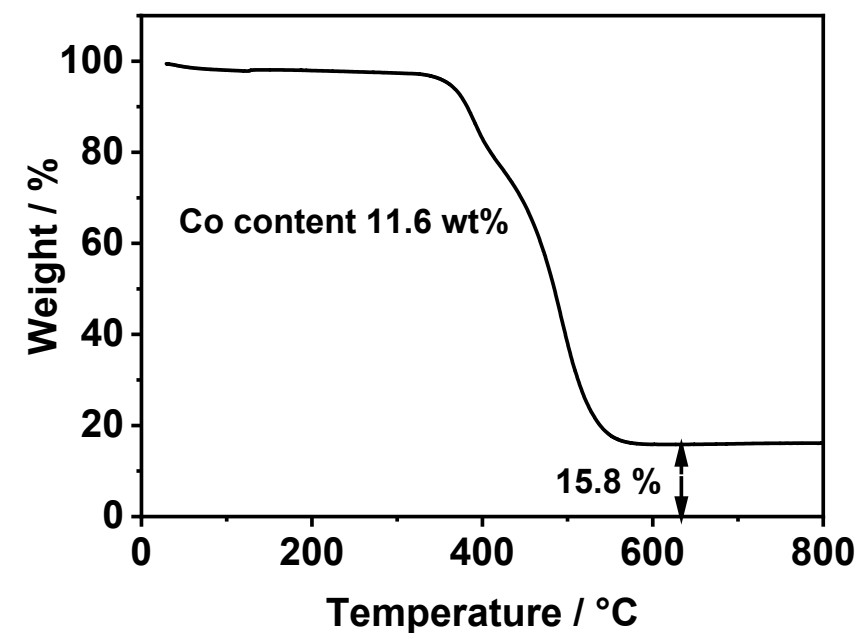

Figure S7. TGA curves of Co@NC tested in air condition. 
Large weight change of the Co@NC sample was observed during the TGA measurement in air, which was caused by the oxidation of $\mathrm{Co}$ to $\mathrm{Co}_{3} \mathrm{O}_{4}$, and the combustion of the $\mathrm{N}$-doped carbon. The residual weight after TGA measurement was $15.8 \mathrm{wt} \%$ of the initial weight of the sample, which raised from the as-formed $\mathrm{Co}_{3} \mathrm{O}_{4}$. Based on the TGA result, the mass content of Co in the Co@NC was 11.6 wt \%.
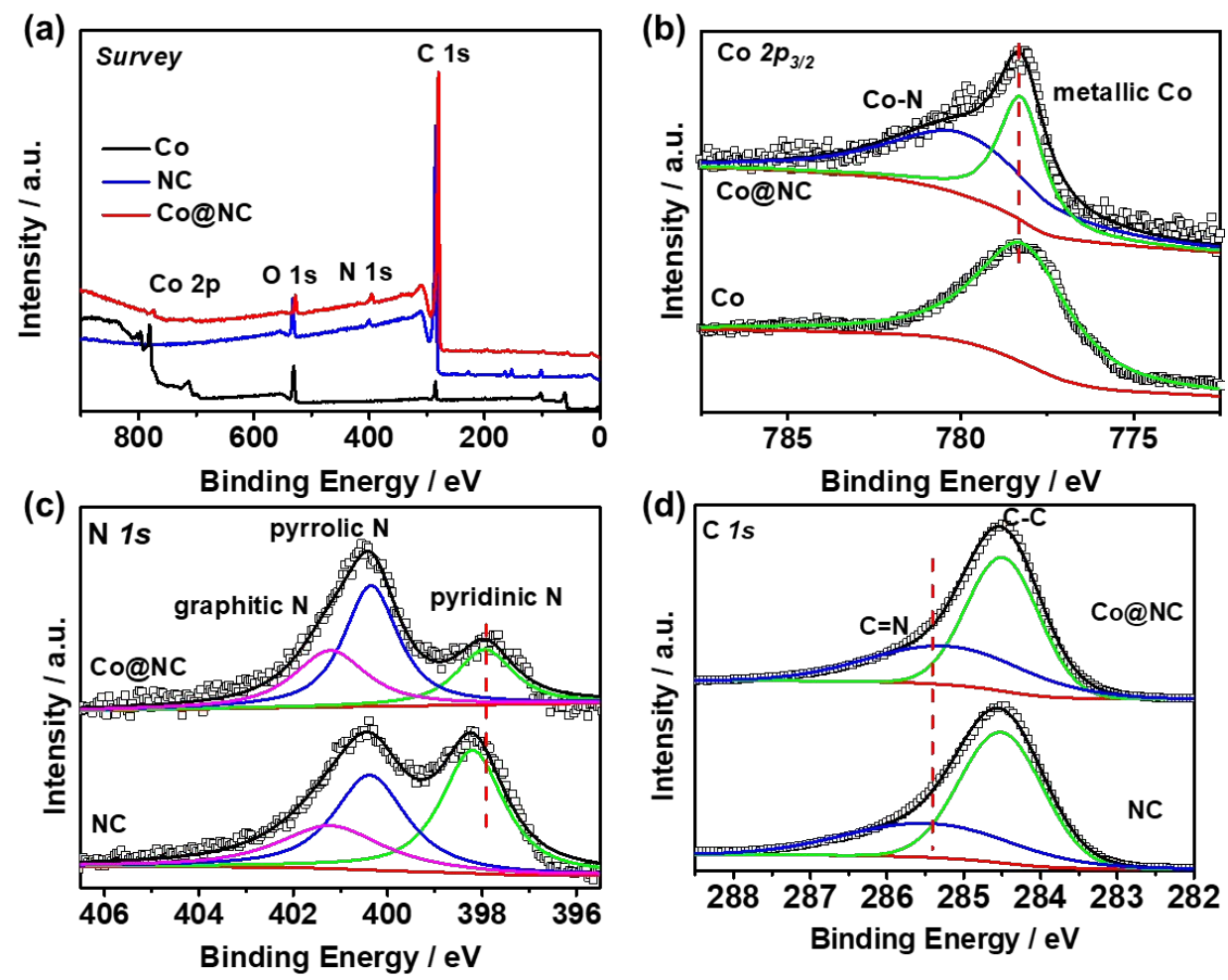

Figure S8. (a) The XPS survey spectra, (b) high-resolution Co $2 p$ spectrum, (c) N 1s spectrum, and (d) C 1s spectrum of Co, NC, and Co@NC samples.
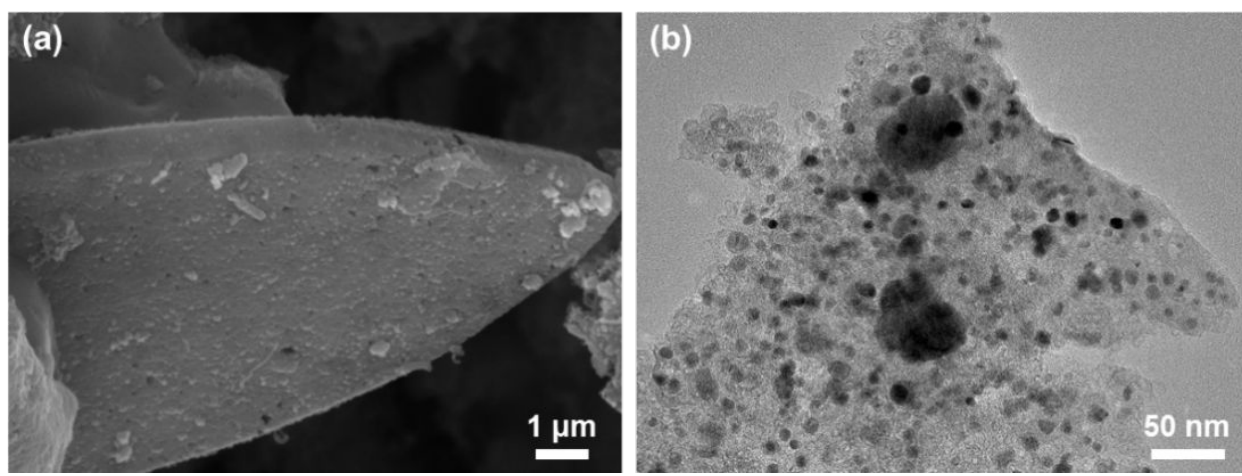

Figure S9. (a) SEM and (b) TEM images of Co. 

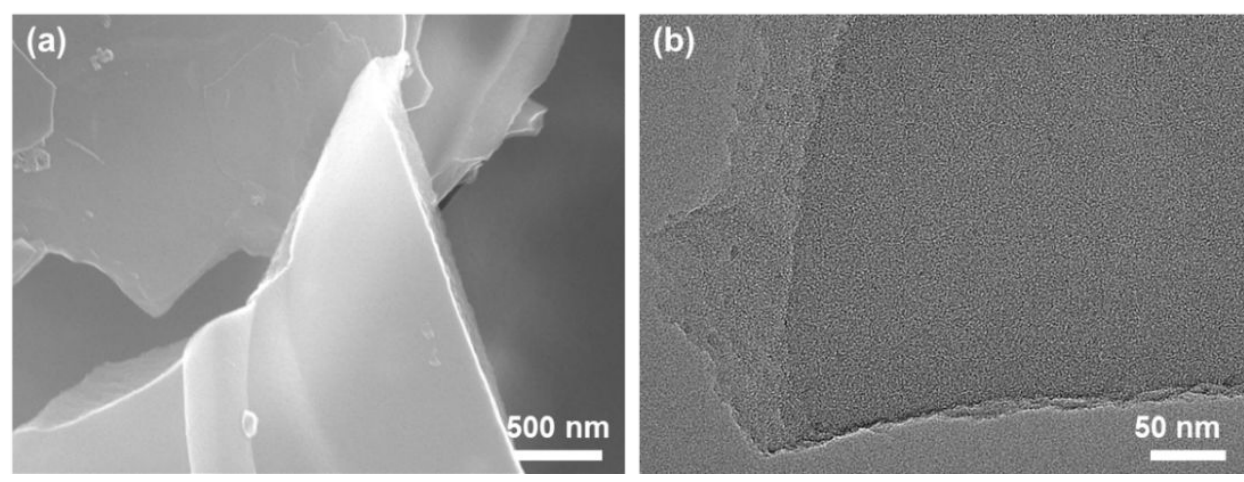

Figure S10. (a) SEM and (b) TEM images of NC.
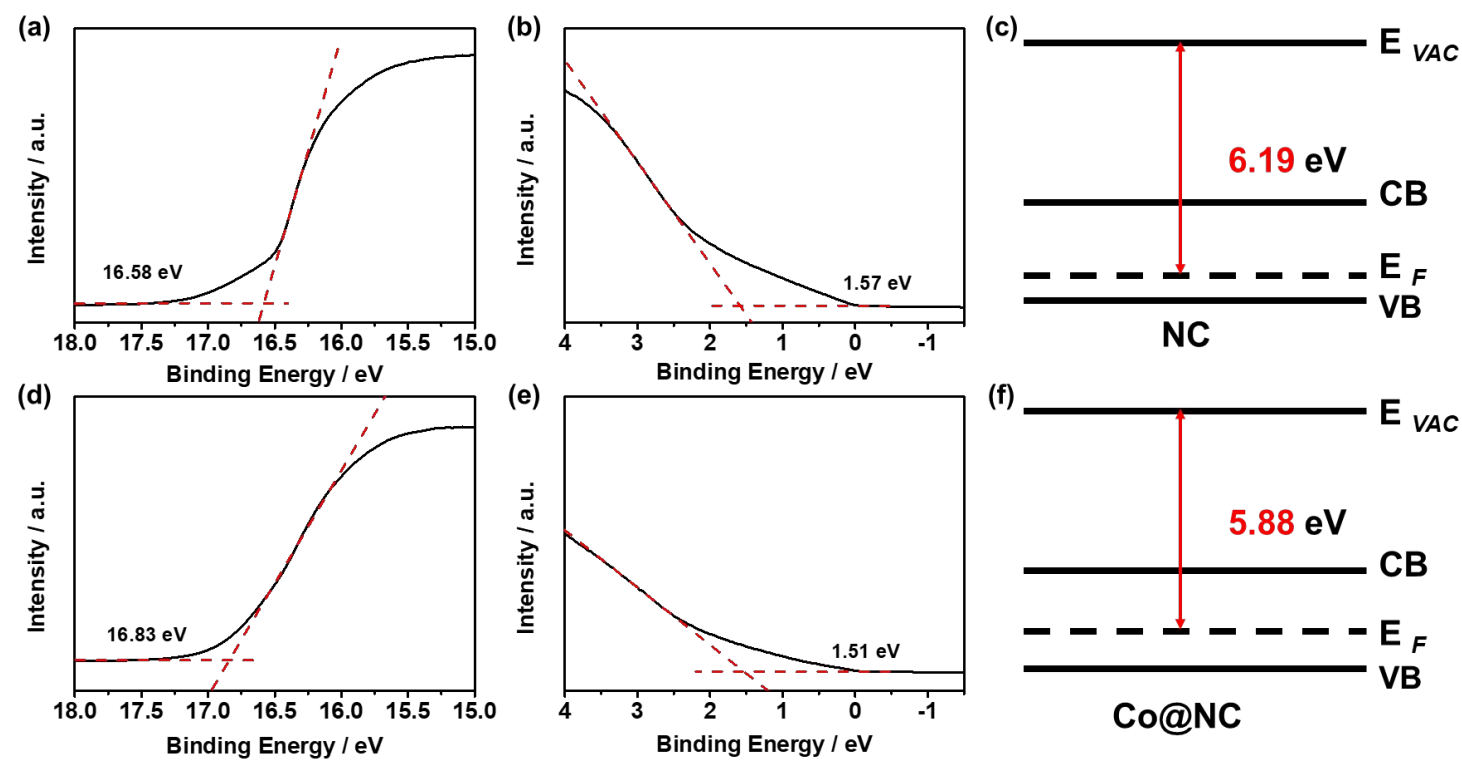

Figure S11. UPS spectra in the cutoff ( $\left.E_{\text {cutoff }}\right)$ of (a) NC and (d) Co@NC. Onset $\left(E_{\mathrm{i}}\right)$ energy regions of (b) NC and (e) Co@NC. The work function of (c) NC and (f) Co@NC.

The ionization energy values (equivalent to the work function $(\Phi)$ of metallic materials) of NC and Co@NC samples were determined by the equation of $\Phi=21.2 \mathrm{eV}$ - $\left(E_{\text {cutoff }}\right.$ - $\left.E_{\mathrm{i}}\right)$ as 6.19 and $5.88 \mathrm{eV}$, respectively. 


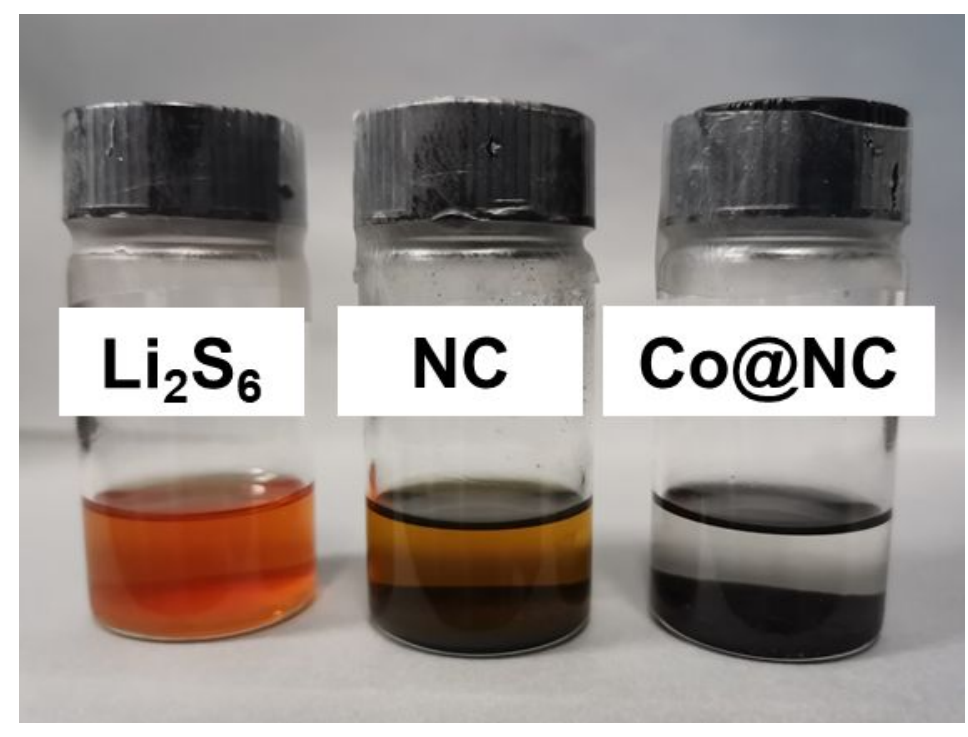

Figure S12. Digital images of initial $0.1 \mathrm{M} \mathrm{Li}_{2} \mathrm{~S}_{6}$ solution, and $0.1 \mathrm{M} \mathrm{Li}_{2} \mathrm{~S}_{6}$ solutions after contacted with $\mathrm{NC}$ and $\mathrm{Co} @ \mathrm{NC}$, respectively.
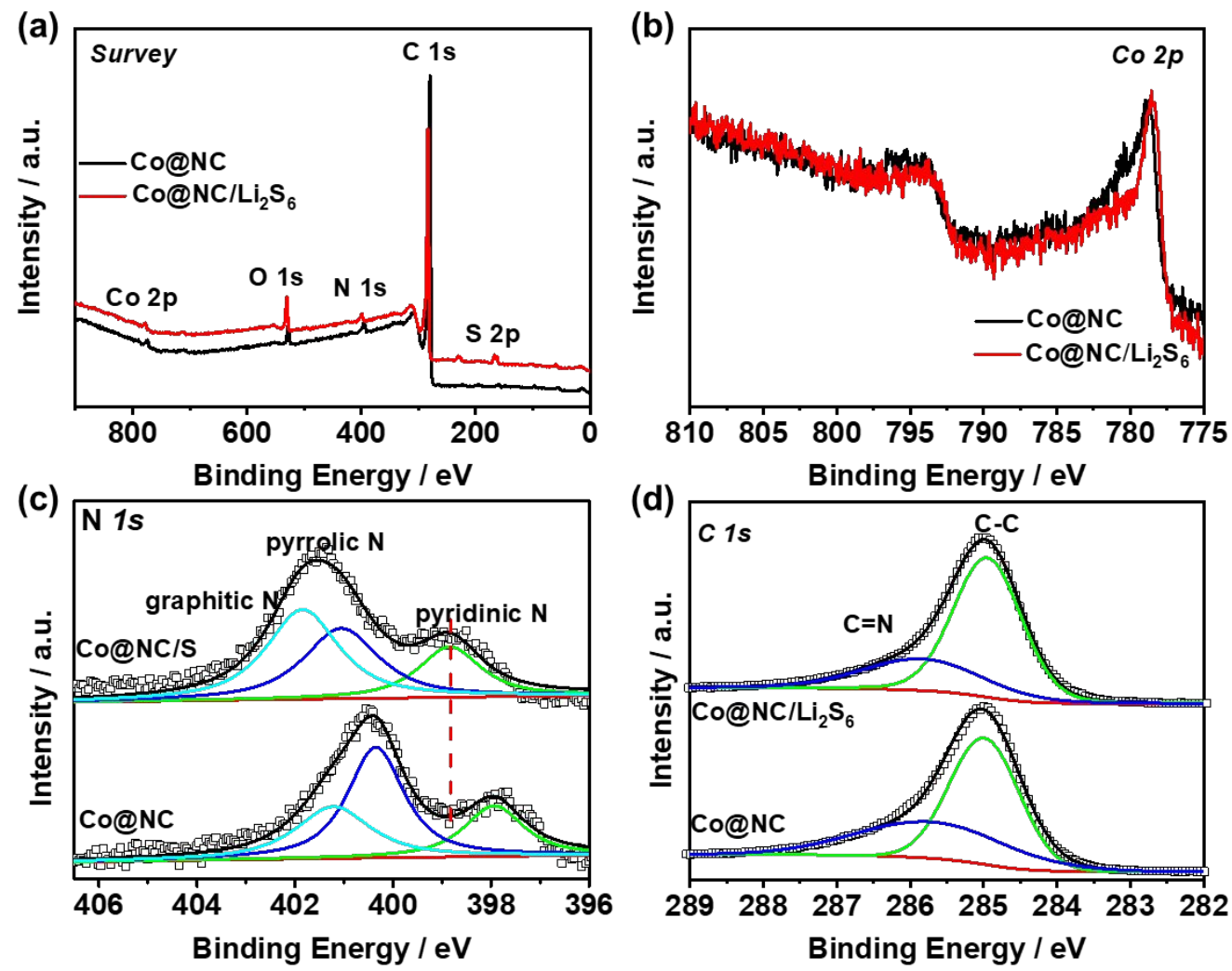

Figure S13. (a) The XPS survey spectrum, (b) Co 2p spectrum, (c) N 1s spectrum, and (d) C 1s spectrum of Co@NC before and after adsorb Li2S6. 


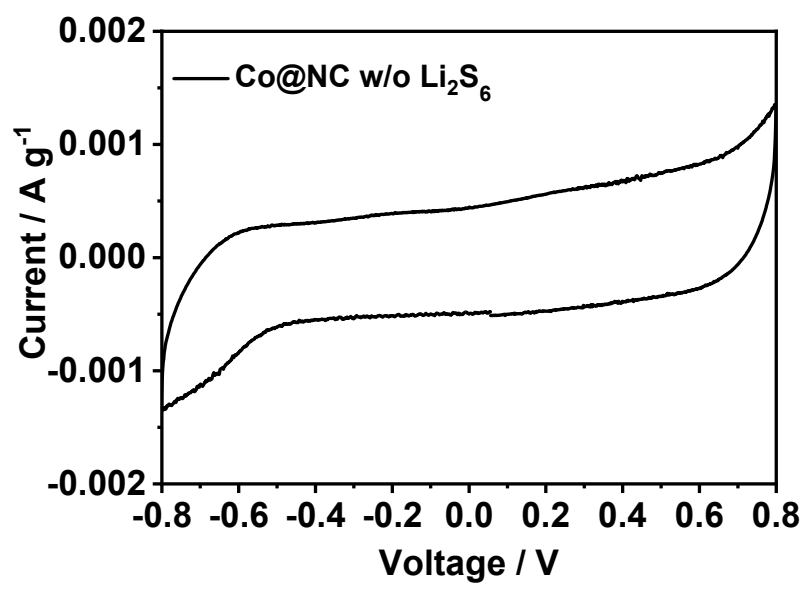

Figure S14. The CV curve of symmetrical cell based on Co@NC using an electrolyte without $\mathrm{Li}_{2} \mathrm{~S}_{6}$.

In the electrolyte without $\mathrm{Li}_{2} \mathrm{~S}_{6}$, a negligible capacitive current density is detected from the $\mathrm{CV}$ curve of $\mathrm{Co} @ \mathrm{NC}$, revealing that the current response mainly comes from the redox conversion of $\mathrm{Li}_{2} \mathrm{~S}_{6}$.

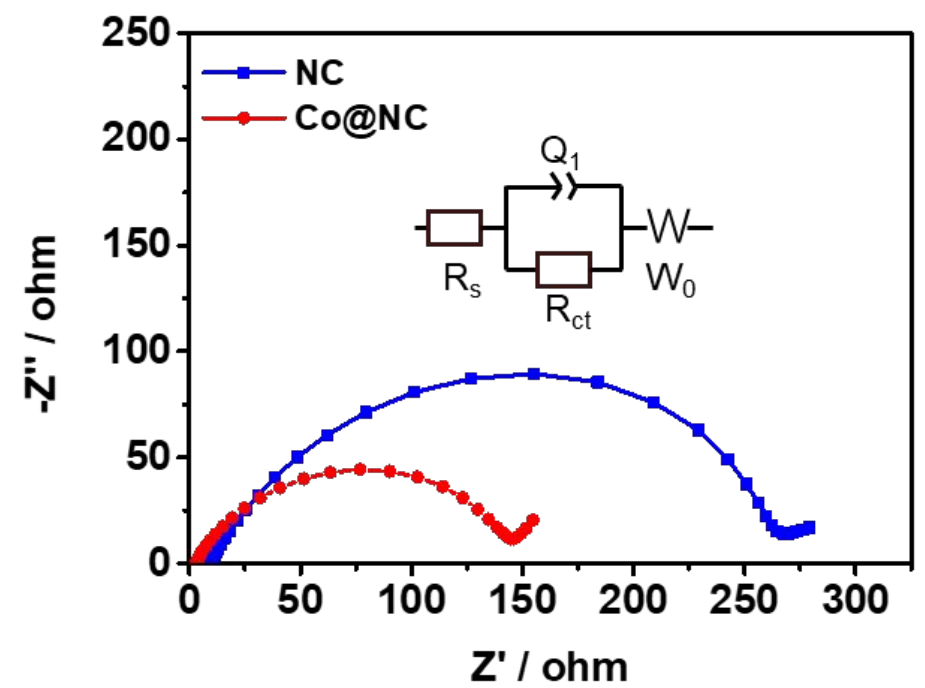

Figure S15. EIS spectra of the symmetrical cells with NC and Co@NC electrodes. 


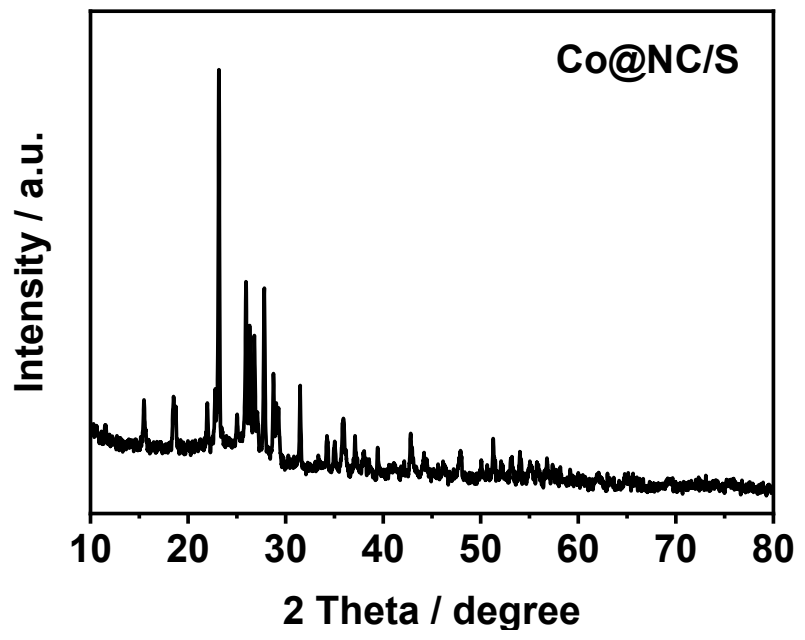

Figure S16. XRD patterns of $\mathrm{Co} @ \mathrm{NC} / \mathrm{S}$ composite.

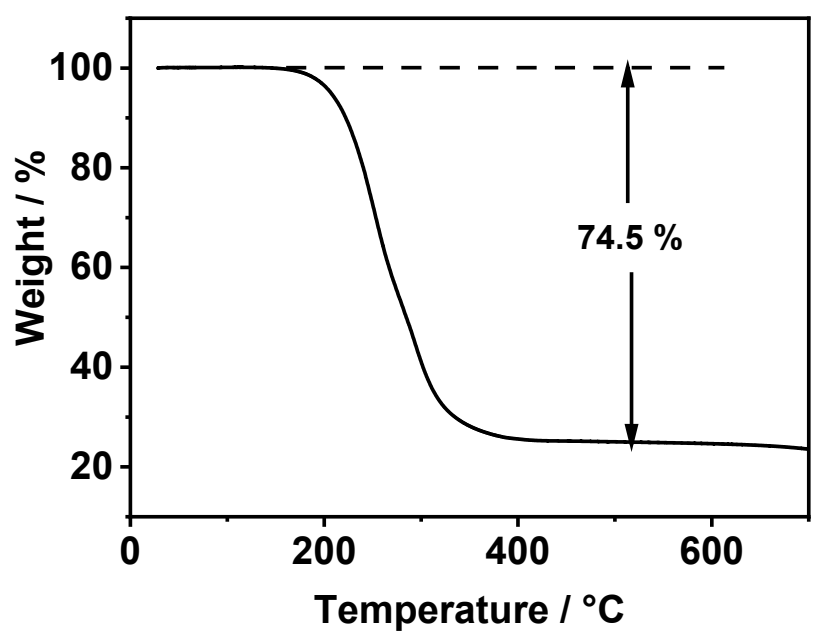

Figure S17. TGA curves of Co@NC/S composite. 

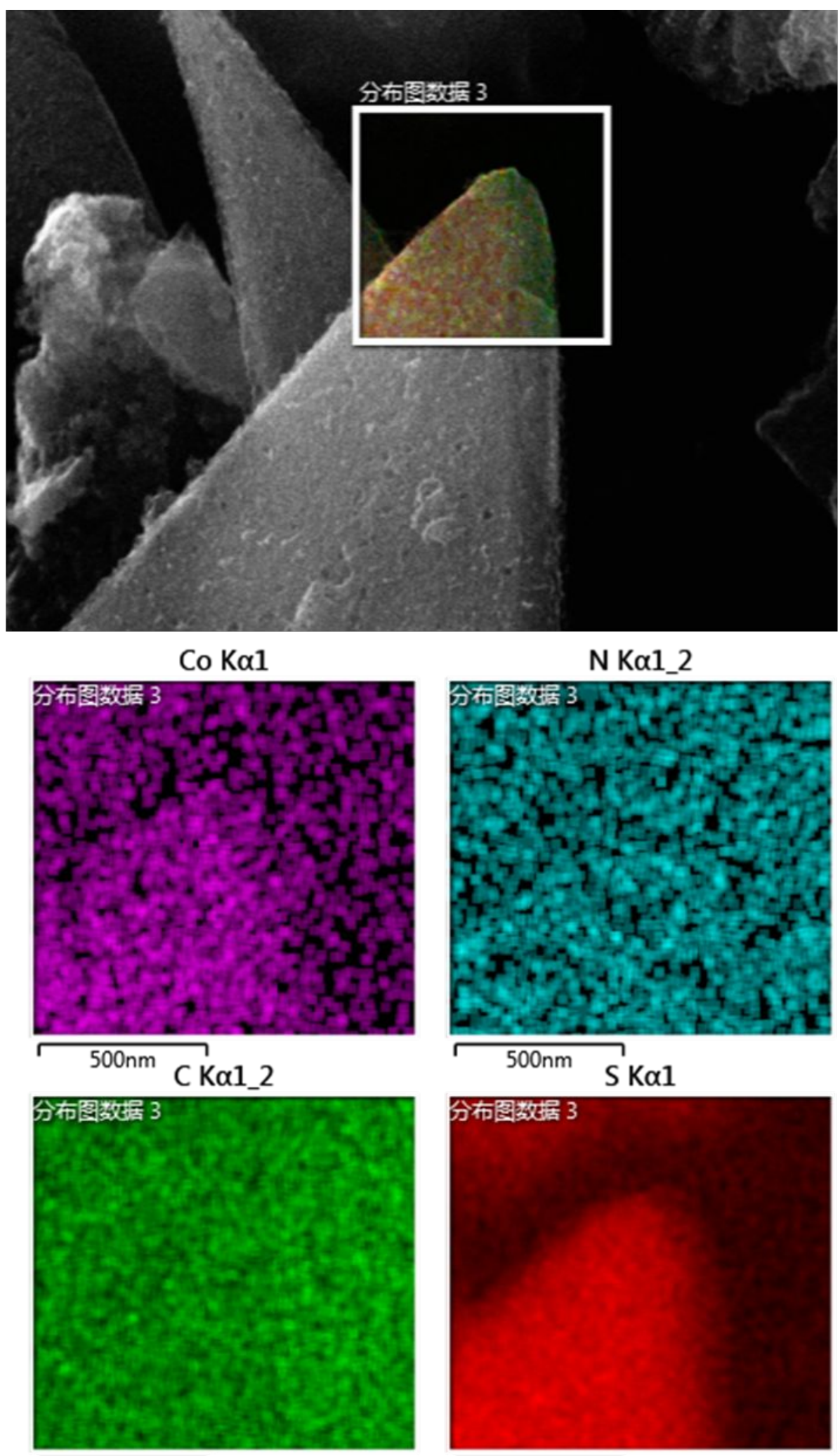

$500 \mathrm{~nm}$

$500 \mathrm{~nm}$

Figure S18. SEM image and corresponding elemental mappings of Co@NC/S composite. 

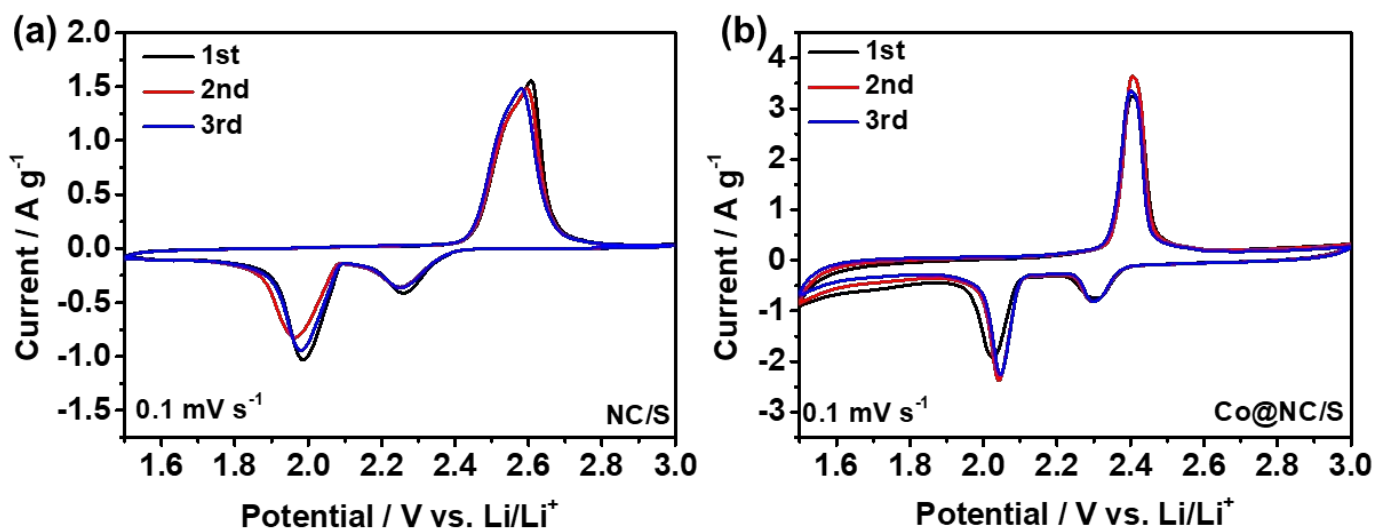

Figure S19. The initial three $\mathrm{CV}$ curves of (a) $\mathrm{NC} / \mathrm{S}$ and (b) $\mathrm{Co} @ \mathrm{NC} / \mathrm{S}$ cathodes at a scan rate of $0.1 \mathrm{mV} \mathrm{s}^{-1}$.

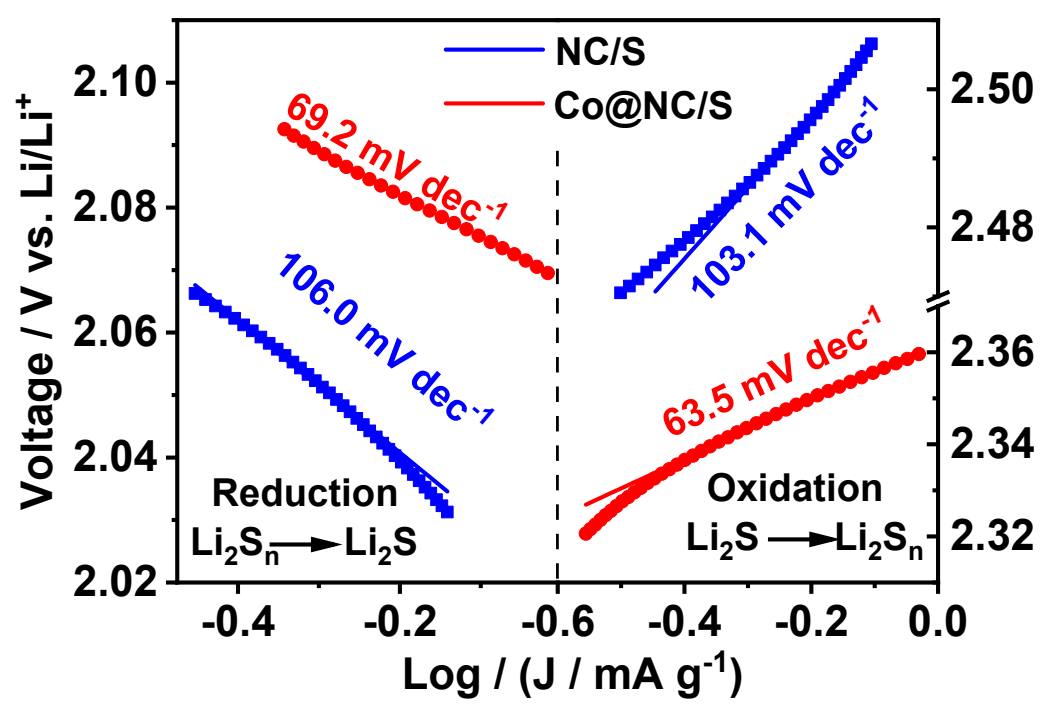

Figure S20. Tafel plots of the second cathodic reduction process (Peak C2: $\mathrm{Li}_{2} \mathrm{~S}_{\mathrm{n}} \rightarrow \mathrm{Li}_{2} \mathrm{~S}$ ) and anodic oxidation process (Peak $\mathrm{A}: \mathrm{Li}_{2} \mathrm{~S} \rightarrow \mathrm{Li}_{2} \mathrm{~S}_{\mathrm{n}}$ ). 

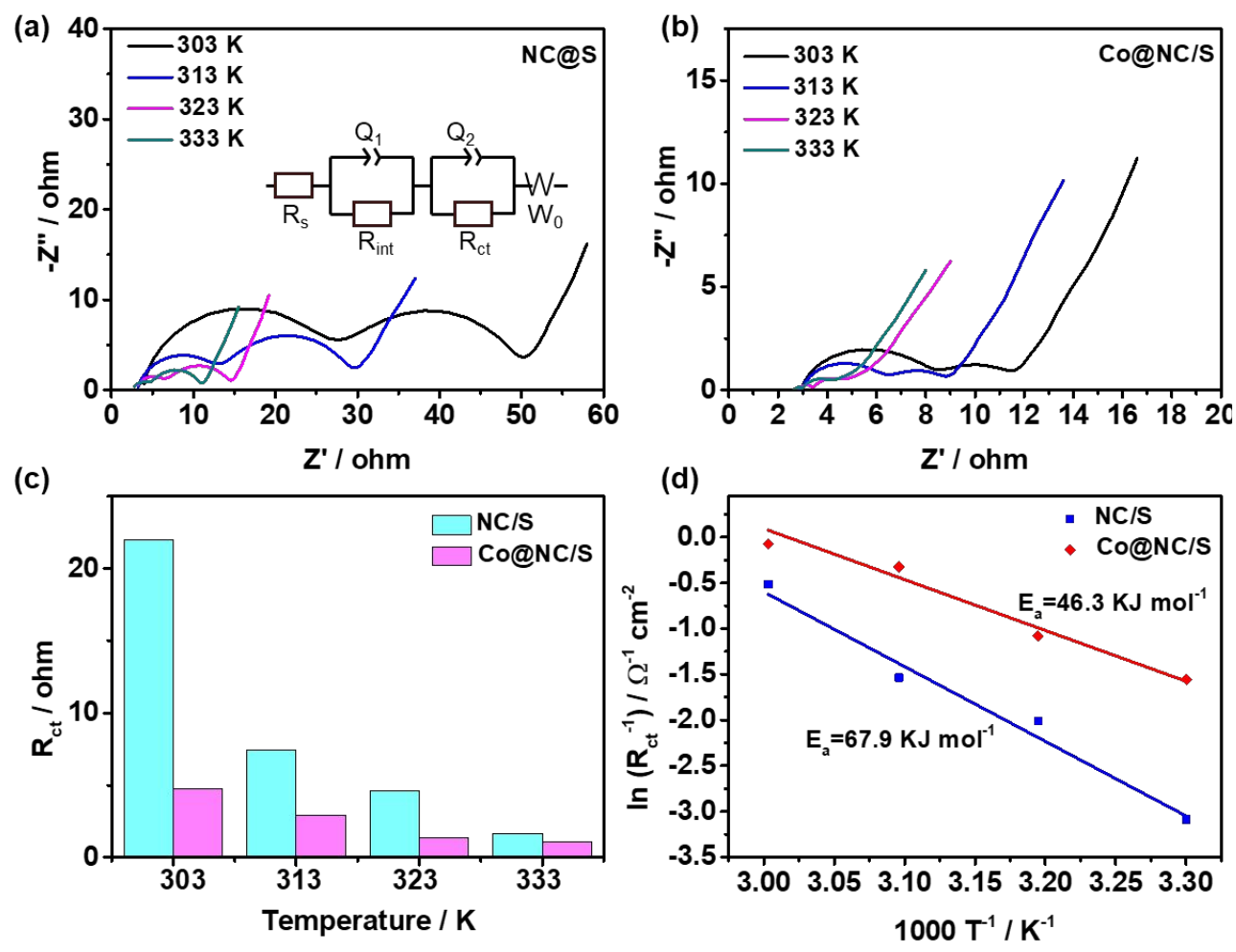

Figure S21. ( $a, b)$ Nyquist plots, (c) bar graph, and (d) linearly fitted graph of the relationship between $\ln \left(\mathrm{R}_{\mathrm{ct}}{ }^{-1}\right)$ and $\mathrm{T}^{-1}$ of $\mathrm{NC} / \mathrm{S}$ and $\mathrm{Co} @ \mathrm{NC} / \mathrm{S}$ cathodes.

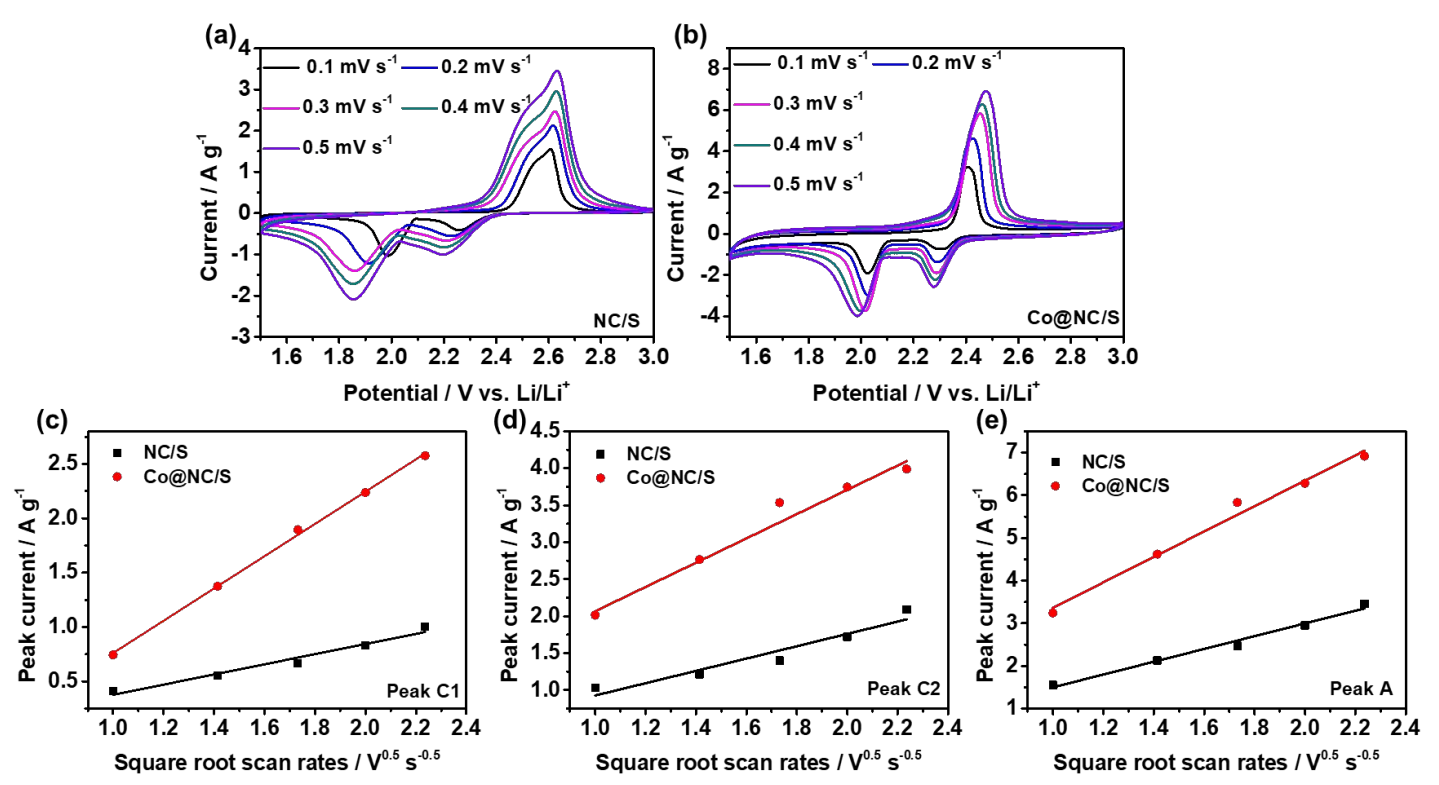

Figure S22. CV curves of (a) NC/S and (b) $\mathrm{Co} @ \mathrm{NC} / \mathrm{S}$ cathodes at various scan rates. Plots of CV peak current for the (c) first cathodic reduction process (IC1: $\mathrm{S}_{8} \rightarrow \mathrm{Li}_{2} \mathrm{~S}_{\mathrm{n}}$ ), (d)second cathodic reduction process (IC2: $\mathrm{Li}_{2} \mathrm{~S}_{\mathrm{n}} \rightarrow \mathrm{Li}_{2} \mathrm{~S}$ ), and (e) anodic oxidation process (IA: $\mathrm{Li}_{2} \mathrm{~S} \rightarrow \mathrm{S}_{8}$ ) versus the square root of the scan rates. 

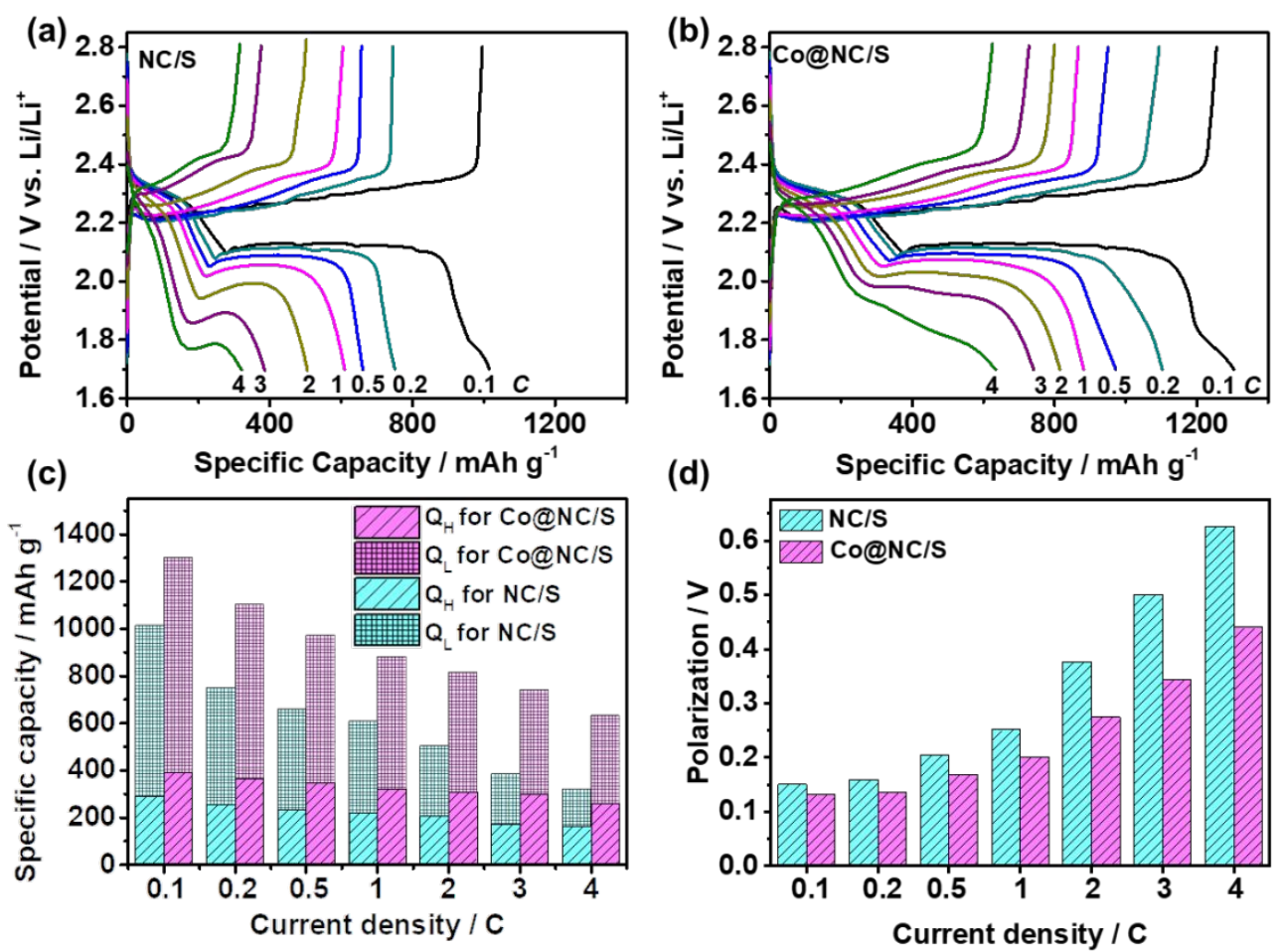

Figure S24. Typical galvanostatic charge-discharge profiles of (a) $\mathrm{NC} / \mathrm{S}$ and (b) Co@NC/S cathodes at $0.1,0.2,0.5,1,2,3$, and $4 C$, respectively. (c) Change of the high-plateau capacity and low-plateau capacity and (d) polarization potentials of $\mathrm{NC} / \mathrm{S}$ and Co@NC/S cathodes at different current densities.
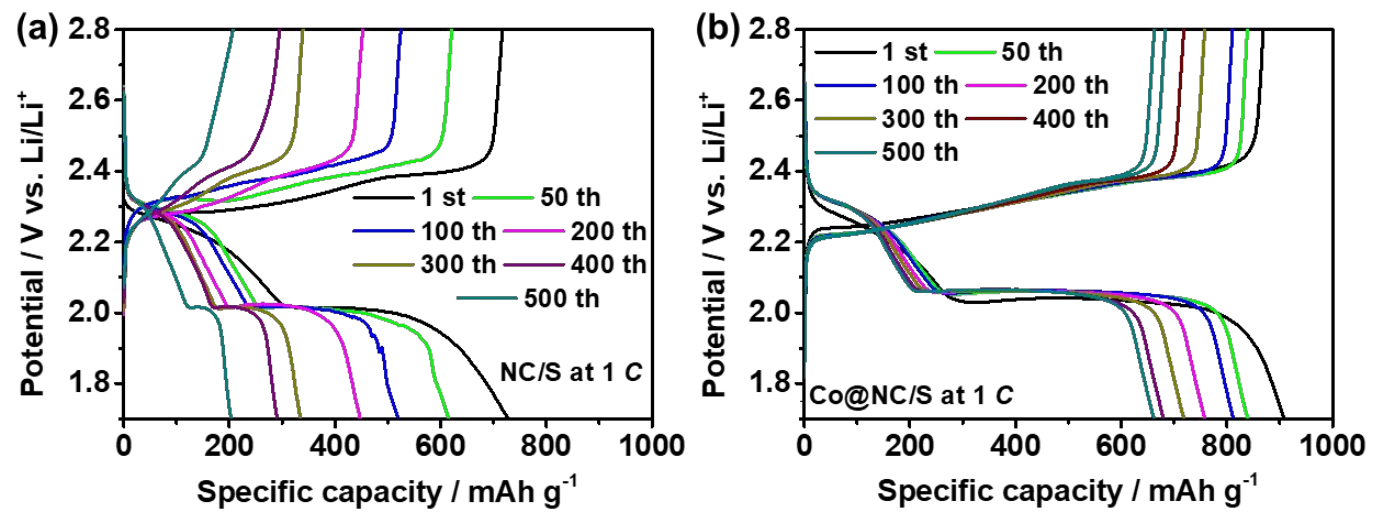

Figure S24. Typical galvanostatic charge-discharge profiles of the (a) NC/S and (b) $\mathrm{Co} @ \mathrm{NC} / \mathrm{S}$ cathodes at $1 C$. 

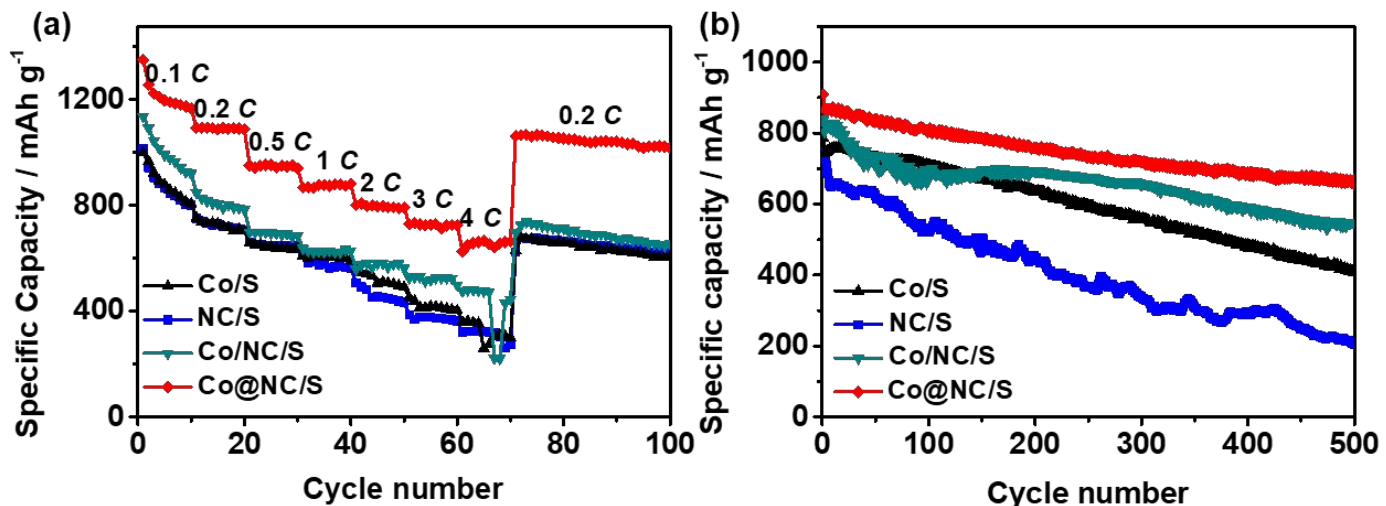

Figure S25. (a) Rate and (b) cycling performance of $\mathrm{Co} / \mathrm{S}, \mathrm{NC} / \mathrm{S}, \mathrm{Co} / \mathrm{NC} / \mathrm{S}$, and Co@NC/S cathodes.
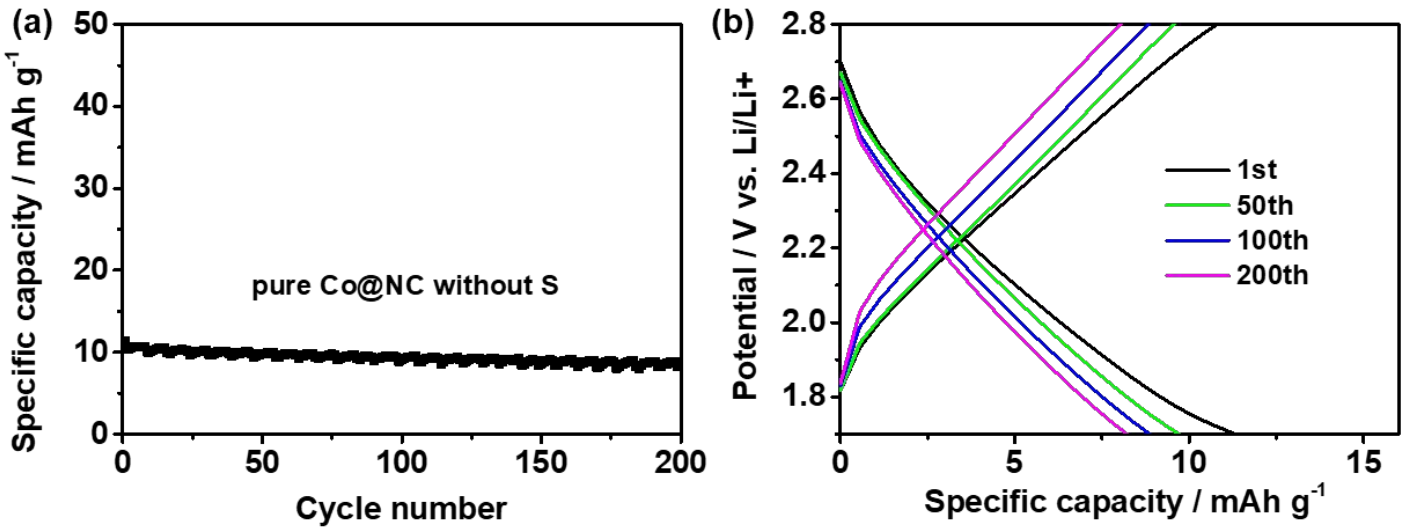

Figure S26. (a, b) Cycling performance of $\mathrm{Co} @ \mathrm{NC}$ cathode without sulfur and typical galvanostatic charge-discharge profiles.

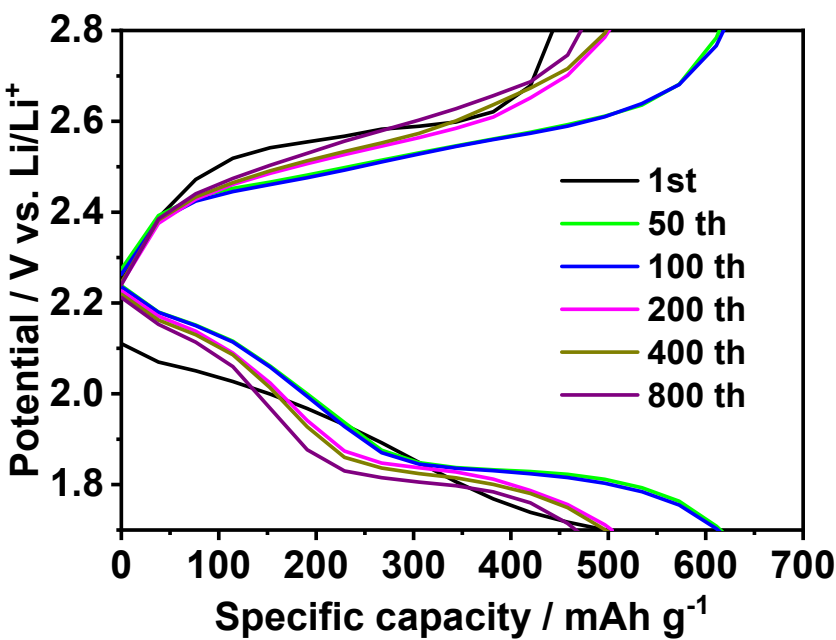

Figure S27. Typical galvanostatic charge-discharge profiles of $\mathrm{Co} @ \mathrm{NC} / \mathrm{S}$ cathode at $4 C$. 

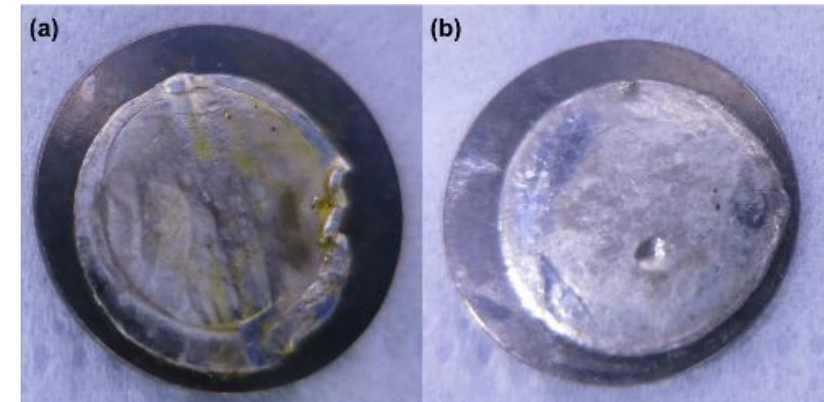

(c)

(d)

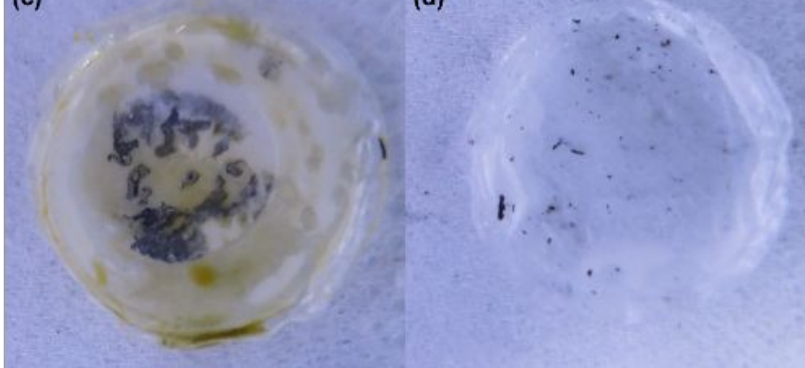

Figure S28. Photographs of cycled $(a, b)$ Li metal anodes and (c, d) separators from Li-S batteries with $(a, c) \mathrm{NC} / \mathrm{S}$ and $(b, d) \mathrm{Co} @ \mathrm{NC} / \mathrm{S}$ cathodes.

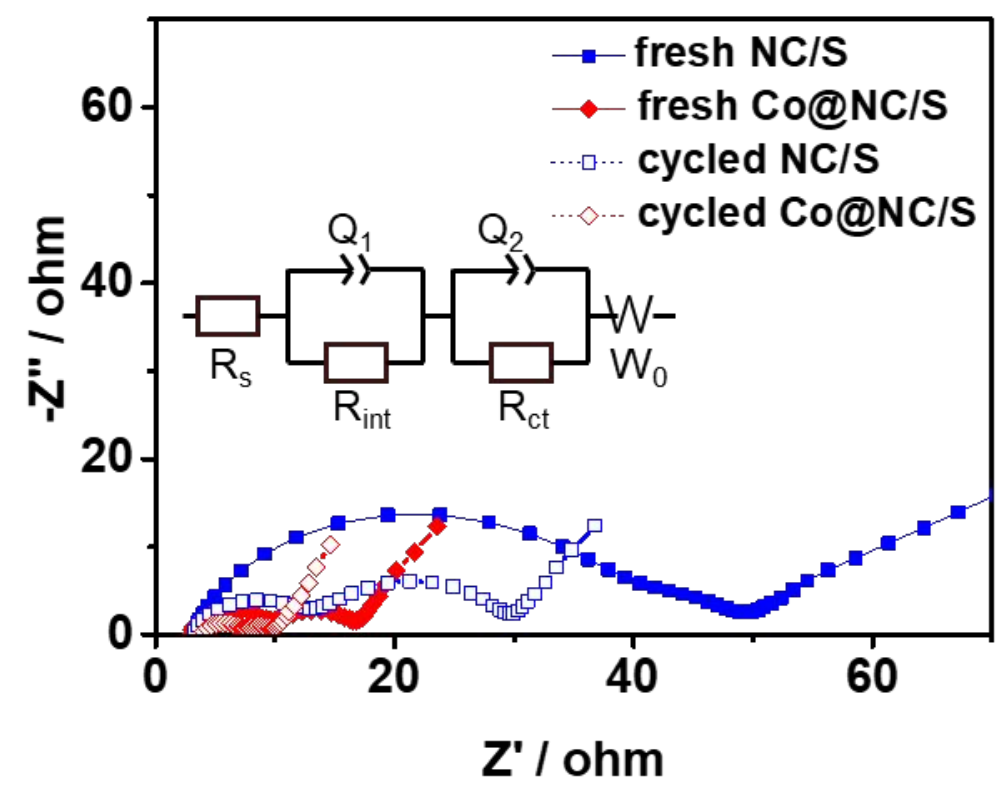

Figure S29. EIS spectra of the NC/S and Co@NC/S cathodes before and after cycling 


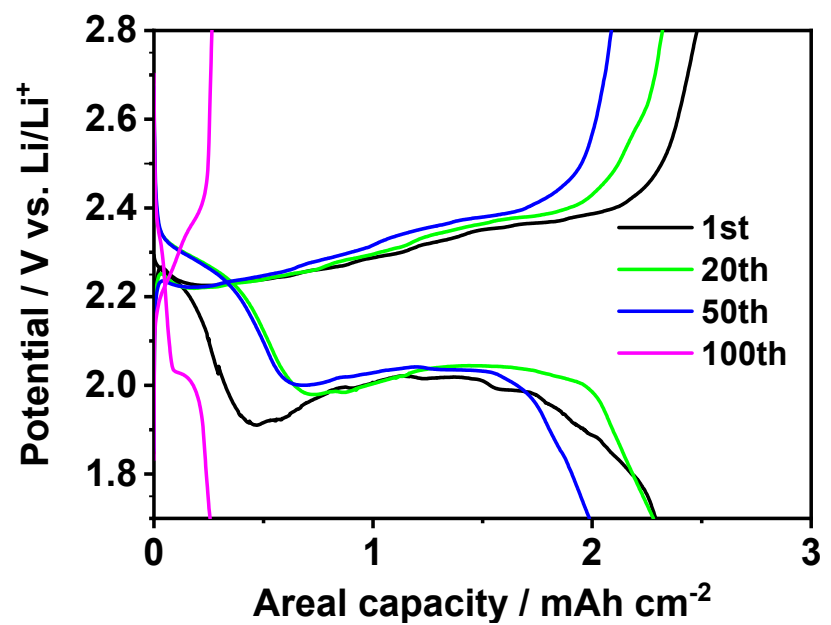

Figure S30. Typical galvanostatic charge-discharge profiles of $\mathrm{NC} / \mathrm{S}$ cathode with a sulfur loading of $3.83 \mathrm{mg}^{-2}$.
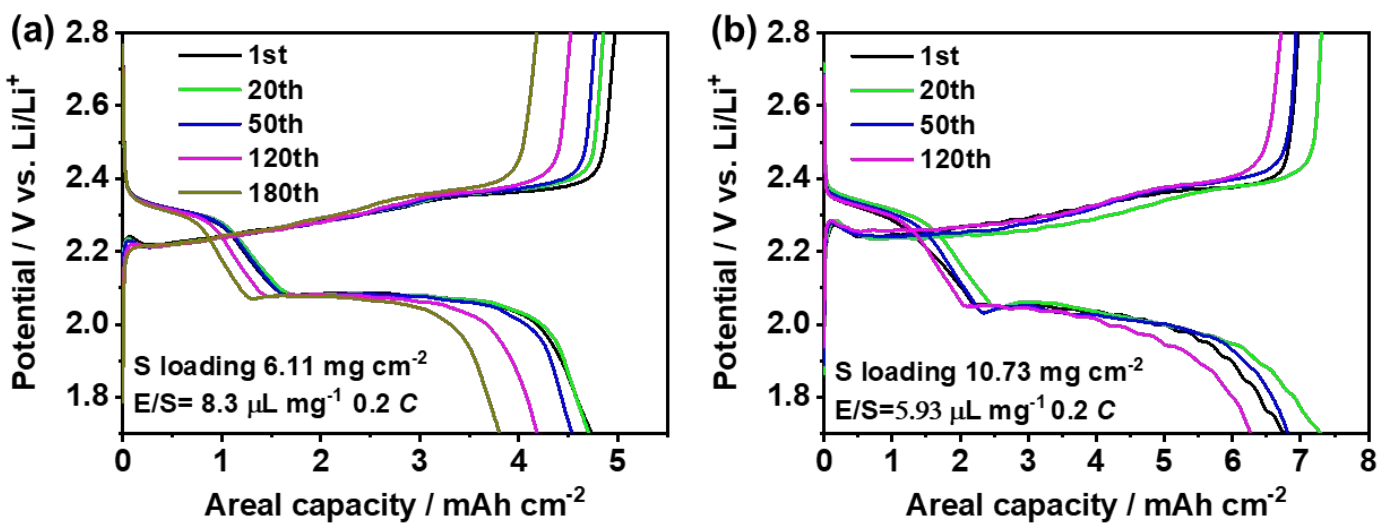

Figure S31. Typical galvanostatic charge-discharge profiles of $\mathrm{Co} @ \mathrm{NC} / \mathrm{S}$ cathode with different sulfur loadings of (a) 6.11 and (b) $10.73 \mathrm{mg}^{-2}$.

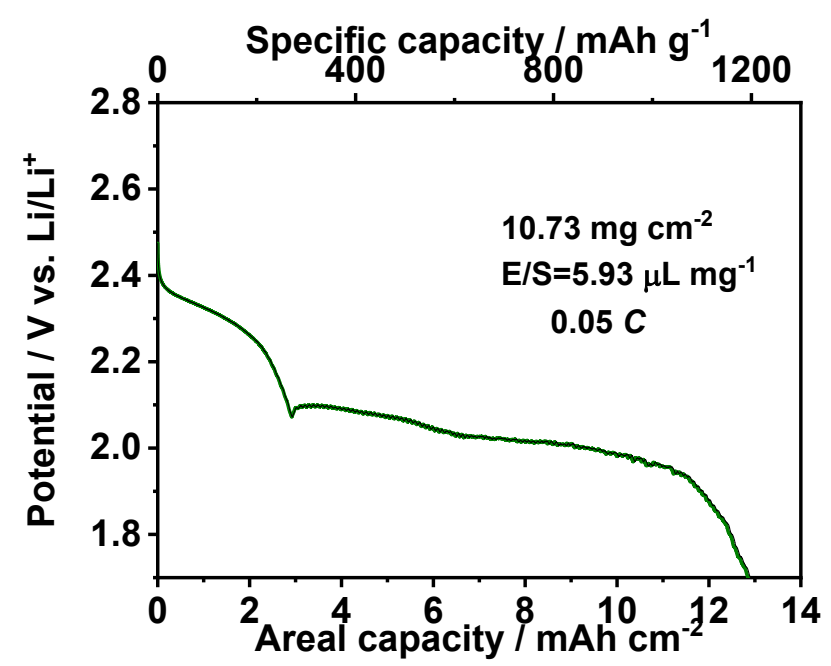

Figure S32. First galvanostatic discharge profiles of $\mathrm{Co} @ \mathrm{NC} / \mathrm{S}$ cathode at $0.05 C$. 

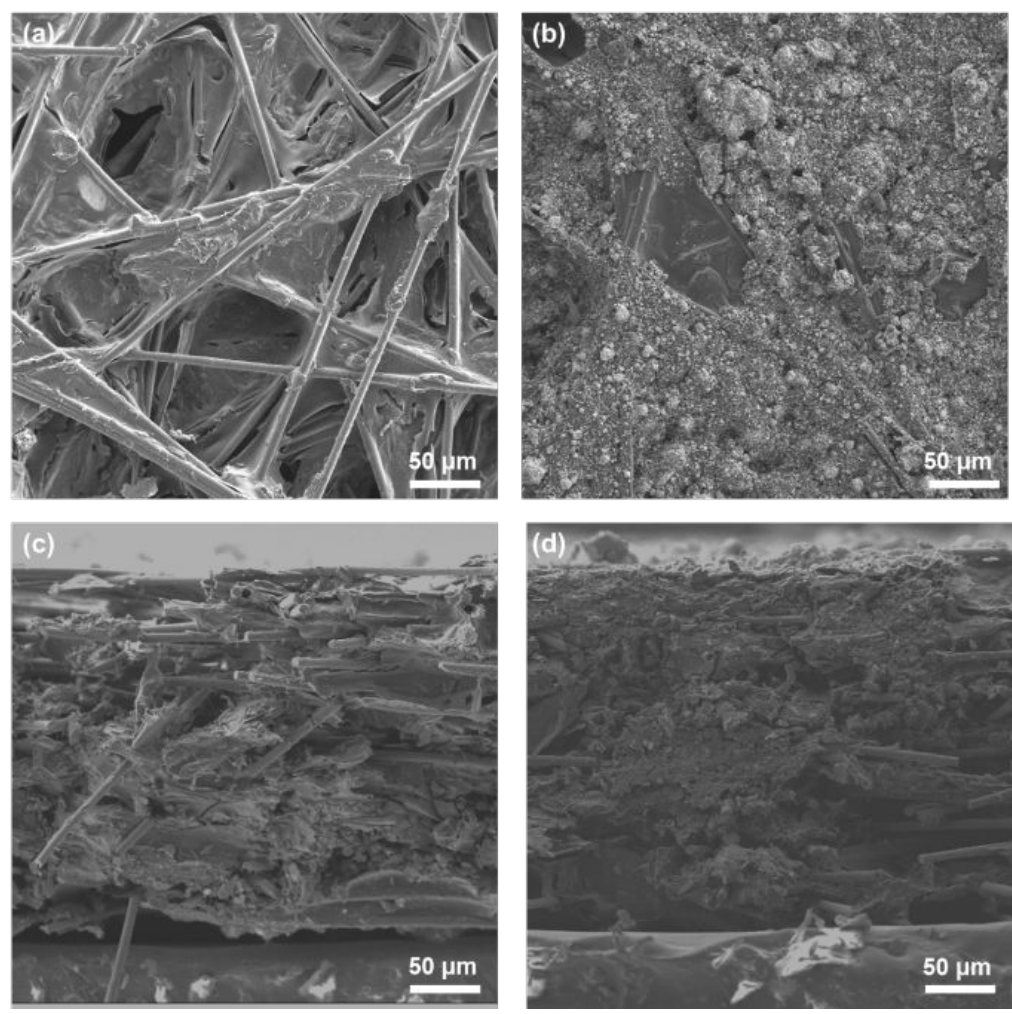

Figure S33. (a, b) Top-view and (c, d) cross-section SEM images of (a, c) fresh carbon paper (CP) and (b, d) Co@NC/S-CP.

(a)

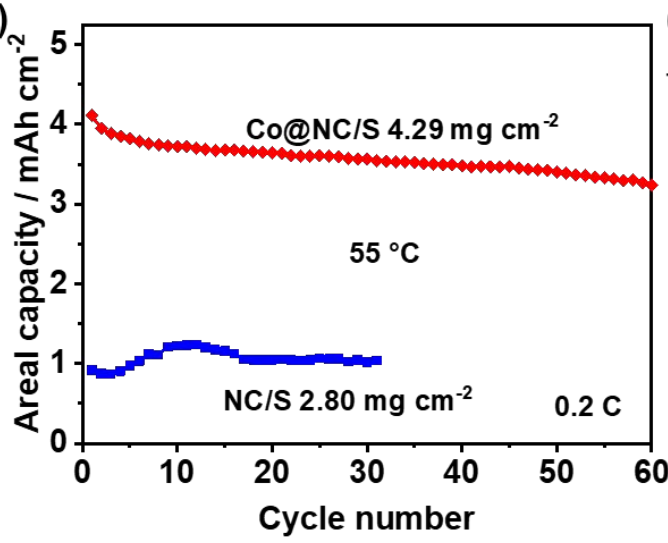

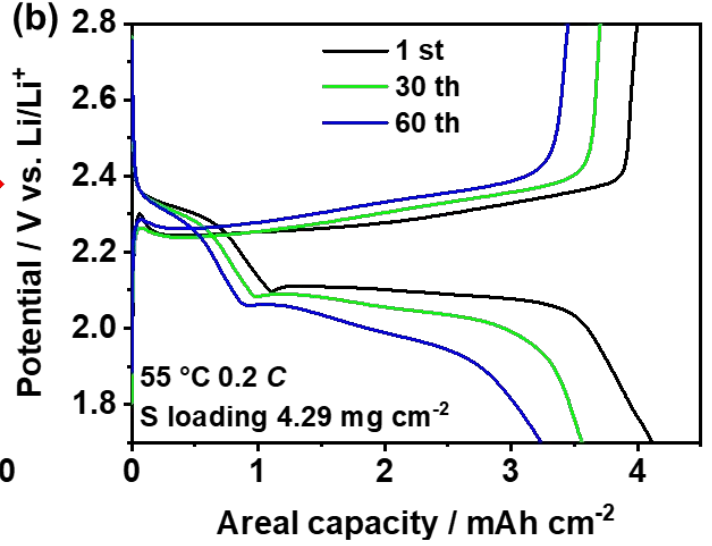

Figure S34. (a) Cycling performance of NC/S and $\mathrm{Co@NC/S}$ cathodes (b) and typical galvanostatic charge-discharge profiles of $\mathrm{Co} @ \mathrm{NC} / \mathrm{S}$ cathode. 
Table S1. Comparison of electrochemical performance of $\mathrm{Co} @ \mathrm{NC} / \mathrm{S}$ cathode with other representative sulfur cathodes in the literatures

\begin{tabular}{|c|c|c|c|c|c|c|c|}
\hline $\begin{array}{l}\text { Sulfur } \\
\text { Host }\end{array}$ & $\begin{array}{l}\text { Sulfur } \\
\text { content }\end{array}$ & $\begin{array}{c}\text { Current } \\
\text { Rate }\end{array}$ & $\begin{array}{l}\text { Cycle } \\
\text { number }\end{array}$ & $\begin{array}{l}\text { Capacity } \\
\left(\mathrm{mAh} \mathrm{g}^{-1}\right)\end{array}$ & $\begin{array}{l}\text { Capacity } \\
\text { retention }\end{array}$ & $\begin{array}{l}\text { Capacity } \\
\text { decay rate }\end{array}$ & Ref \\
\hline Co@NC & $\begin{array}{r}74.5 \\
w t \%\end{array}$ & $4 C$ & 800 & 370.4 & $90.1 \%$ & $0.012 \%$ & $\begin{array}{l}\text { This } \\
\text { work }\end{array}$ \\
\hline N-PC@uCo & $76 \mathrm{wt} \%$ & $1 C$ & 500 & 788.9 & $86.5 \%$ & $0.027 \%$ & [11] \\
\hline $\begin{array}{l}\text { Co-CNT } \\
\text { @MXene }\end{array}$ & $70 w t^{0} \%$ & $1 \mathrm{C}$ & 840 & 378 & $45.0 \%$ & $0.064 \%$ & [12] \\
\hline $\begin{array}{l}\mathrm{Fe}-\mathrm{N}-\mathrm{C} \\
/ \mathrm{S}-\mathrm{MCF}\end{array}$ & $60 \mathrm{wt} \%$ & 0.5 & 1000 & 1064.7 & $69.0 \%$ & $0.031 \%$ & [13] \\
\hline Co-N-C & $70 \mathrm{wt} \%$ & 0.2 & 200 & 864 & $60.0 \%$ & $0.2 \%$ & [14] \\
\hline $\begin{array}{l}\mathrm{Co}-\mathrm{NGC} \\
\text { @ } \mathrm{NCNF}\end{array}$ & $70 \mathrm{wt} \%$ & $2 C$ & 500 & 556.9 & $83.0 \%$ & $0.034 \%$ & [15] \\
\hline CNTs/CoS-NSs & $\begin{array}{l}76.5 \\
w t \%\end{array}$ & $1 C$ & 500 & 711.9 & $72.5 \%$ & $0.055 \%$ & [16] \\
\hline $\begin{array}{c}\mathrm{CoP} @ \mathrm{HPCN} \\
\text {-MWCNT }\end{array}$ & $70 \mathrm{wt} \%$ & $0.2 C$ & 300 & 630 & $76.9 \%$ & $0.077 \%$ & [17] \\
\hline $\mathrm{Co}-\mathrm{CNCs}$ & $\begin{array}{l}74.5 \\
w t \%\end{array}$ & $2 C$ & 600 & 704.8 & $82.6 \%$ & $0.029 \%$ & [18] \\
\hline $\mathrm{CP} / \mathrm{Fe}-\mathrm{N}-\mathrm{GOMC}$ & $73 \mathrm{wt} \%$ & $0.5 C$ & 500 & 604 & $62.5 \%$ & $0.075 \%$ & [19] \\
\hline $\mathrm{V}_{8} \mathrm{C}_{7}-\mathrm{VO}_{2}$ & $\begin{array}{l}78.5 \\
w t \%\end{array}$ & $4 \mathrm{C}$ & 900 & 420.1 & $54.9 \%$ & $0.061 \%$ & [20] \\
\hline $\mathrm{TiO}_{2}-\mathrm{Ni}_{3} \mathrm{~S}_{2} / \mathrm{rGO}$ & 80 wt $\%$ & $0.5 \mathrm{C}$ & 900 & 638 & $65 \%$ & $0.039 \%$ & {$[21]$} \\
\hline Co@BNCNs YS & $80 \mathrm{wt} \%$ & $1 C$ & 400 & 700.0 & $76.0 \%$ & $0.06 \%$ & [22] \\
\hline $\mathrm{E}-\mathrm{Co}_{\mathrm{x}} \mathrm{Sn}_{\mathrm{y}} / \mathrm{NC}$ & $72 w t \%$ & $1 C$ & 500 & 714 & $81.2 \%$ & $0.0377 \%$ & [23] \\
\hline $\mathrm{TiS}_{2} @ \mathrm{NSC}$ & $70 \mathrm{wt} \%$ & $1 C$ & 200 & 695 & $68.2 \%$ & $0.159 \%$ & [24] \\
\hline Co@NHCRs & $60 \mathrm{wt} \%$ & $0.5 C$ & 100 & 704 & $72.5 \%$ & $0.0275 \%$ & [25] \\
\hline $\begin{array}{c}\mathrm{S} / \mathrm{NiO}- \\
\mathrm{NiCo}_{2} \mathrm{O}_{4} @ \mathrm{C}\end{array}$ & $73 \mathrm{wt} \%$ & $0.5 C$ & 500 & 717 & $70.5 \%$ & $0.059 \%$ & [26] \\
\hline $\mathrm{Sn}_{0.063} \mathrm{MoO}_{3}$ & $\begin{array}{l}67.4 \\
w t \%\end{array}$ & $1 C$ & 500 & 724.6 & $80.0 \%$ & $0.04 \%$ & [27] \\
\hline $\mathrm{TiN}$ & $72 \mathrm{wt} \%$ & $0.5 C$ & 450 & 693.7 & $66.7 \%$ & $0.074 \%$ & [28] \\
\hline MC-NS & $86 \mathrm{wt} \%$ & $0.2 C$ & 100 & 907.5 & $77 \%$ & $0.225 \%$ & [29] \\
\hline $\mathrm{NC} / \mathrm{MoS}_{3}$ & $70 \mathrm{wt} \%$ & $0.5 C$ & 500 & 752 & $62.1 \%$ & $0.076 \%$ & {$[30]$} \\
\hline VS@NT & - & $2 C$ & 1200 & 455 & $55.6 \%$ & $0.037 \%$ & {$[31]$} \\
\hline $\mathrm{N}-\mathrm{CoSe}_{2}$ & $70 \mathrm{wt} \%$ & $2 C$ & 500 & 754.7 & $81.5 \%$ & $0.037 \%$ & {$[32]$} \\
\hline
\end{tabular}




\begin{tabular}{cccccccc}
$\mathrm{CS} @ \mathrm{HPP}$ & $72 \mathrm{wt} \%$ & $2 \mathrm{C}$ & 1200 & 414.3 & $52 \%$ & $0.04 \%$ & {$[33]$} \\
$\mathrm{Ta}_{2} \mathrm{O}_{5-\mathrm{x}} / \mathrm{MCN}$ & 66.2 & $1 \mathrm{C}$ & 1000 & 680 & $71 \%$ & $0.029 \%$ & {$[34]$} \\
$\mathrm{Fe}_{1-\mathrm{x}} \mathrm{S}-\mathrm{NC}$ & $70 \mathrm{wt} \%$ & $0.5 \mathrm{wt} \%$ & 200 & 793 & $84 \%$ & $0.080 \%$ & {$[35]$} \\
$\mathrm{CPZC}$ & 75.2 & $1 \mathrm{C}$ & 2000 & 712 & $68 \%$ & $0.016 \%$ & {$[36]$} \\
\hline
\end{tabular}

Table S2. Comparison of areal capacity of the Co@NC@S cathode with recently reported sulfur cathodes with sulfur mass loading higher than $5 \mathrm{mg} \mathrm{cm}^{-2}$.

\begin{tabular}{|c|c|c|c|c|c|}
\hline $\begin{array}{l}\text { Cathode } \\
\text { materials }\end{array}$ & $\begin{array}{l}\text { loading } \\
\left(\mathrm{mg} \mathrm{cm}^{-2}\right)\end{array}$ & 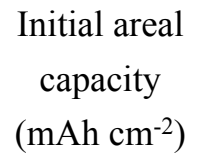 & $\begin{array}{c}\text { E/S } \\
\text { Ratio } \\
\left(\mathrm{mL} \mathrm{g}^{-1}\right)\end{array}$ & Capacity retention & Ref \\
\hline Co@NC & 10.73 & 6.74 & 8.3 & $\begin{array}{c}80.5 \% \\
(\text { after } 180 \text { cycles at } 0.2 C \text { ) } \\
92.1 \% \\
\text { (after } 120 \text { cycles at } 0.2 C \text { ) }\end{array}$ & $\begin{array}{l}\text { This } \\
\text { work }\end{array}$ \\
\hline N-PC@uCo/S & 5.9 & 4.8 & - & $\begin{array}{c}90.0 \% \\
\text { (after } 100 \text { cycles at } 0.2 C \text { ) }\end{array}$ & {$[11]$} \\
\hline $\mathrm{Fe}-\mathrm{N}-\mathrm{C} / \mathrm{S}-\mathrm{MCF}$ & 5.2 & 5.5 & 20 & $\begin{array}{c}84.0 \% \\
\text { (after } 500 \text { cycles at } 3 C \text { ) }\end{array}$ & {$[13]$} \\
\hline $\begin{array}{l}\mathrm{Co}-\mathrm{NGC} \\
@ \mathrm{NCNF} / \mathrm{S}\end{array}$ & 6.5 & 4.78 & 12 & $\begin{array}{c}90.0 \% \\
\text { (after } 150 \text { cycles at } 0.5 C \text { ) }\end{array}$ & [15] \\
\hline $\begin{array}{l}\mathrm{CP} / \mathrm{Fe}-\mathrm{N}- \\
\mathrm{GOMC}\end{array}$ & 5.98 & 5.5 & - & $\begin{array}{c}78 \% \\
(\text { after } 200 \text { cycles at } 1 C)\end{array}$ & [19] \\
\hline TiS ${ }_{2} @ \mathrm{NSC} @ S$ & 7.7 & 7.9 & 8 & $\begin{array}{c}74.7 \% \\
\text { (after } 100 \text { cycles at } 0.1 \mathrm{C} \text { ) }\end{array}$ & [24] \\
\hline VS@NT & 9.6 & 9.1 & 8 & $\begin{array}{c}78.1 \% \\
\text { (after } 120 \text { cycles at } 0.1 C \text { ) }\end{array}$ & [31] \\
\hline $\mathrm{N}-\mathrm{CoSe}_{2}$ & 6.37 & 6.67 & 6.0 & $\begin{array}{c}87.4 \% \\
\text { (after } 70 \text { cycles at } 0.2 \mathrm{C} \text { ) }\end{array}$ & {$[32]$} \\
\hline $\mathrm{Ta}_{2} \mathrm{O}_{5-\mathrm{x}} / \mathrm{MCN}$ & 5.6 & 5 & 3.6 & $\begin{array}{c}80.0 \% \\
\text { (after } 200 \text { cycles at } 0.2 C \text { ) }\end{array}$ & [34] \\
\hline $\mathrm{VTe}_{2} @ \mathrm{MgO}$ & 6.9 & 6.5 & 10 & $\begin{array}{c}76.8 \% \\
\text { (after } 50 \text { cycles at } 0.1 \mathrm{C})\end{array}$ & [36] \\
\hline S@Co-N/G & 6 & 5.1 & 12 & $\begin{array}{c}90.0 \% \\
\text { (after } 100 \text { cycles at } 0.2 C \text { ) }\end{array}$ & {$[37]$} \\
\hline
\end{tabular}


Table S3 Design parameters for calculations of cell specific energy density.

\begin{tabular}{cc}
\hline Design parameters for calculations of cell specific energy density \\
\hline Cell part & Mass of material for Li-S cell (mg) \\
Li anode (50\% excess) & 3.9 \\
Electrolyte & 50 \\
Separator & 2.55 \\
S cathode (including additives) & 14.1 \\
\hline
\end{tabular}

The gravimetric energy density was calculated from ${ }^{[38]}$ :

$W_{\text {cell }}=E_{\text {cell }} * Q^{*} m_{s} / M_{\text {cell }}=2.15 \mathrm{~V} * 1199.7 \mathrm{mAh} \mathrm{g}^{-1} * 8.42 \mathrm{mg} /(3.9+50+2.55+14.1) \mathrm{mg}$ $=307.9 \mathrm{Wh} \mathrm{kg}^{-1}$

Where $W_{\text {cell }}$ is the energy density $\left(\mathrm{Wh} \mathrm{kg}^{-1}\right), E_{\text {cell }}(\mathrm{V})$ is the average reversible potential (2.15 V vs. $\left.\mathrm{Li} / \mathrm{Li}^{+}\right), Q$ is the specific capacity of sulfur $\left(1199.7 \mathrm{mAh} \mathrm{g}^{-1}\right)$, and $M_{\text {cell }}(\mathrm{mg})$ is the total mass of the Li-S cell.

Table S4. Comparison of energy density of the Co@NC@S cathode with recent works.

\begin{tabular}{|c|c|c|c|c|c|c|}
\hline $\begin{array}{l}\text { Cathode } \\
\text { materials }\end{array}$ & $\begin{array}{l}\text { loading } \\
\left(\mathrm{mg} \mathrm{cm}^{-2}\right)\end{array}$ & $\begin{array}{l}\text { Current } \\
\text { density }\end{array}$ & $\begin{array}{c}\text { Areal } \\
\text { capacity } \\
\left(\mathrm{mAh} \mathrm{cm}^{-2}\right)\end{array}$ & $\begin{array}{c}\mathrm{E} / \mathrm{S} \\
\text { Ratio } \\
\left(\mathrm{mL} \mathrm{g}^{-1}\right)\end{array}$ & $\begin{array}{c}\text { Energy } \\
\text { Density } \\
\left(\mathrm{Wh} \cdot \mathrm{kg}^{-1}\right)\end{array}$ & Ref \\
\hline $\mathrm{Co} @ \mathrm{NC} / \mathrm{S}$ & 10.73 & $0.05 C$ & 12.87 & 5.9 & 307.8 & $\begin{array}{l}\text { This } \\
\text { work }\end{array}$ \\
\hline VS@NT-S & 9.6 & $0.1 C$ & 13.02 & 8 & 243.4 & [31] \\
\hline $\mathrm{S} @ \mathrm{CPZC}$ & 13.5 & $0.05 C$ & 14.2 & 4.5 & 360.9 & [36] \\
\hline $\mathrm{PCF} / \mathrm{VN} / \mathrm{S}$ & 8.1 & - & 10.61 & 20 & 127.4 & [40] \\
\hline $\mathrm{S} / \mathrm{CNT} / \mathrm{NF}$ & 8.1 & $0.25 \mathrm{C}$ & 8 & 30 & 65.7 & [41] \\
\hline S@CNTF & 7.1 & $0.1 C$ & 9 & 11 & 210.5 & [42] \\
\hline $\mathrm{S} @ \mathrm{CF}$ & 2.32 & - & 3.75 & 8.7 & 314.1 & [43] \\
\hline G-HPC/S & 3.6 & $0.5 C$ & 4.26 & 11 & 196.8 & [44] \\
\hline SWCNT/CNF/S & 16 & $0.1 \mathrm{C}$ & 12.3 & 15 & 96.6 & [45] \\
\hline NCF-S@rGO & 8.8 & $0.1 C$ & 6.6 & 9 & 150.9 & [46] \\
\hline
\end{tabular}


Table S5. Comparison of high-temperature electrochemical performance of the $\mathrm{Co} @ \mathrm{NC} / \mathrm{S}$ cathode with recent works.

\begin{tabular}{|c|c|c|c|c|c|}
\hline $\begin{array}{c}\text { Sulfur } \\
\text { Host }\end{array}$ & Separator & $\begin{array}{l}\text { Sulfur loading } \\
\left(\mathrm{mg} \mathrm{cm}^{-2}\right)\end{array}$ & $\begin{array}{c}\text { Temperature } \\
\left({ }^{\circ} \mathrm{C}\right)\end{array}$ & $\begin{array}{l}\text { Initial capacity } \\
\left(\mathrm{mAh} \mathrm{g}^{-1}\right)\end{array}$ & Ref \\
\hline $\mathrm{Co} @ \mathrm{NC} / \mathrm{S}$ & Celgard & 4.29 & 55 & 957.4 at $0.2 C$ & This work \\
\hline $\begin{array}{l}\mathrm{S} @ \mathrm{CNTs} / \\
\mathrm{Co}_{3} \mathrm{~S}_{4} \mathrm{NBs}\end{array}$ & Celgard & 1.2 & 50 & 953 at $0.2 C$ & [47] \\
\hline $\begin{array}{c}\text { Alucone } \\
\text { coated C/S }\end{array}$ & Celgard & - & 55 & 1055 at $0.1 C$ & [48] \\
\hline RGO@S & $\begin{array}{c}\mathrm{Li} @ \text { Nafion/P } \\
\mathrm{EP} / \mathrm{Al}_{2} \mathrm{O}_{3}\end{array}$ & - & 60 & 1172 at $0.2 C$ & [49] \\
\hline $\begin{array}{c}\text { Porous } \\
\text { graphene/S }\end{array}$ & Celgard & 1 & 60 & 590 at $1 C$ & [50] \\
\hline $\begin{array}{c}\mathrm{CTNF} @ \mathrm{CoS}_{2} \\
\text {-CNA/S }\end{array}$ & Celgard & 2.91 & 55 & 1126 at $0.5 C$ & [51] \\
\hline $\begin{array}{c}\text { BN/graphene- } \\
\text { S }\end{array}$ & Celgard & 1.5 & 55 & 1100 at $0.5 C$ & [52] \\
\hline Super P/S & $\begin{array}{c}\mathrm{MnS} / \mathrm{CNF} \\
\text { /Celgard }\end{array}$ & 2.0 & 60 & 1080 at $0.5 C$ & [53] \\
\hline
\end{tabular}

\section{Supplementary references}

[1] T. Wang, Z. Kou, S. Mu, J. Liu, D. He, I. S. Amiinu, W. Meng, K. Zhou, Z. Luo, S. Chaemchuen, F. Verpoort, Adv. Funct. Mater. 2018, 28, 1705048.

[2] C. Luo, X. Liang, Y. Sun, W. Lv, Y. Sun, Z. Lu, W. Hua, H. Yang, R. Wang, C. Yan, J. Li, Y. Wan, Q.-H. Yang, Energy Storage Mater. 2020, 33, 290-297.

[3] P. Hohenberg, W. Kohn, Phys. Rev. 1964, 136, B864-B871.

[4] W. Kohn, L. J. Sham, Phys. Rev. 1965, 140 (4A), A1133.

[5] G. Kresse, J. Hafner, Phys. Rev. B 1993, 47 (1), 558. 
[6] P. E. Blöchl, Phys. Rev. B 1994, 50 (24), 17953.

[7] G. Kresse, J. Furthmüller, Phys. Rev. B 1996, 54 (16), 11169-11186.

[8] J. Perdew, K. Burke, M. Ernzerhof, Phys. Rev. Lett. 1996, 77 (18), 3865-3868.

[9] S. Grimme, J. Comput. Chem. 2006, 27 (15), 1787-1799.

[10] G. Henkelman, B. P. Uberuaga, H. Jónsson, J. Chem. Phys. 2000, 113 (22), 9901-9904.

[11] R. Wang, J. Yang, X. Chen, Y. Zhao, W. Zhao, G. Qian, S. Li, Y. Xiao, H. Chen, Y. Ye, G. Zhou, F. Pan Adv. Energy Mater. 2020, 10, 1903550.

[12] C. Xiong, G. Y. Zhu, H. R. Jiang, Q. Chen, T. S. Zhao, Energy Storage Mater. 2020, 33, 147-157.

[13] W. G. Lim, Y. Mun, A. Cho, C. Jo, S. Lee, J. W. Han, J. Lee, ACS Nano 2018. 18, 6013-6022.

[14] Y.-J. Li, J.-M. Fan, M.-S. Zheng, Q.-F. Dong, Energy Environ. Sci. 2016, 9, 1998-2004.

[15] M. Yu, S. Zhou, Z. Wang, Y. Wang, N. Zhang, S. Wang, J. Zhao, J. Qiu, Energy Storage Mater. 2019, 20, 98-107.

[16] L. Ma, W. Zhang, L. Wang, Y. Hu, G. Zhu, Y. Wang, R. Chen, T. Chen, Z. Tie, J. Liu, Z. Jin, ACS Nano 2018. 12, 4868-4876.

[17] Z. Ye, Y. Jiang, J. Qian, W. Li, T. Feng, L. Li, F. Wu, R. Chen, Nano Energy 2019, 64. 103965.

[18] Q. Wu, X. Zhou, J. Xu, F. Cao, C. Li, ACS Nano 2019, 13, 9520-9532.

[19] H. Li, D. Liu, X. Zhu, D. Qu, Z. Xie, J. Li, H. Tang, D. Zheng, D. Qu, Nano Energy 2020, 73. 104763.

[20] J. Cai, J. Jin, Z. Fan, C. Li, Z. Shi, J. Sun, Z. Liu, Adv. Mater. 2020, 32, 2005967.

[21] R. Wang, C. Luo, T. Wang, G. Zhou, Y. Deng, Y. He, Q. Zhang, F. Kang, W. Lv, Q. H. Yang, Adv. Mater. 2020, 32, 2000315.

[22] S.-K. Park, J.-K. Lee, Y. C. Kang, Adv. Funct. Mater. 2018, 28, 1705264.

[23] Z. Qiao, F. Zhou, Q. Zhang, F. Pei, H. Zheng, W. Xu, P. Liu, Y. Ma, Q. Xie, L. Wang, X. Fang, D.-L. Peng, Energy Storage Mater. 2019, 23, 62-71.

[24] X. Huang, J. Tang, B. Luo, R. Knibbe, T. Lin, H. Hu, M. Rana, Y. Hu, X. Zhu, Q. Gu, D. Wang, L. Wang, Adv. Energy Mater. 2019, 9, 1901872.

[25] M. Zhang, C. Yu, C. Zhao, X. Song, X. Han, S. Liu, C. Hao, J. Qiu, Energy Storage Mater. 2016, 5, 223-229.

[26] L. Hu, C. Dai, H. Liu, Y. Li, B. Shen, Y. Chen, S.-J. Bao, M. Xu, Advanced Energy Mater. 2018, 8, 1800709.

[27] W. Yang, J. Xiao, Y. Ma, S. Cui, P. Zhang, P. Zhai, L. Meng, X. Wang, Y. Wei, Z. Du, B. Li, Z. Sun, S. Yang, Q. Zhang, Y. Gong, Adv. Energy Mater. 2019. 9, 1803137.

[28] W. G. Lim, C. Jo, A. Cho, J. Hwang, S. Kim, J. W. Han, J. Lee, Adv. Mater. 2019, 31, 1806547.

[29] J. Li, C. Chen, Y. Chen, Z. Li, W. Xie, X. Zhang, M. Shao, M. Wei, Adv. Energy Mater. 2019, 9, 1901935.

[30] J. Yu, J. Xiao, A. Li, Z. Yang, L. Zeng, Q. Zhang, Y. Zhu, L. Guo, Angew. Chem. Int. Ed. 2020, 59, 2-10. 
[31] S. Wang, H. Chen, J. Liao, Q. Sun, F. Zhao, J. Luo, X. Lin, X. Niu, M. Wu, R. Li, X. Sun, ACS Energy Letters 2019, 4, 755-762.

[32] M. Wang, L. Fan, X. Sun, B. Guan, B. Jiang, X. Wu, D. Tian, K. Sun, Y. Qiu, X. Yin, Y. Zhang, N. Zhang, ACS Energy Lett. 2020, 5, 3041-3050.

[33] Z. Ye, Y. Jiang, L. Li, F. Wu, R. Chen, Adv. Mater. 2020, 32, 2002168.

[34] Z. Zhang, D. Luo, G. Li, R. Gao, M. Li, S. Li, L. Zhao, H. Dou, G. Wen, S. Sy, Y. Hu, J. Li, A. Yu, Z. Chen, Matter 2020, 3, 1-15.

[35] Y. Boyjoo, H. Shi, E. Olsson, Q. Cai, Z.-S. Wu, J. Liu, G. Lu Adv. Energy Mater. 2020, 10, 2000651.

[36] G. Li, W. Lei, D. Luo, Y. Deng, Z. Deng, D. Wang, A. Yu, Z. Chen, Energy Environ. Sci. 2018. 11, 2372-2381.

[37] M. Wang, Y. Song, Z. Sun, Y. Shao, C. Wei, Z. Xia, Z. Tian, Z. Liu, J. Sun, ACS Nano 2019, 13, 13235-13243.

[38] Z. Du, X. Chen, W. Hu, C. Chuang, S. Xie, A. Hu, W. Yan, X. Kong, X. Wu, H. Ji, L. J. Wan, J. Am. Chem. Soc. 2019, 141, 3977-3985.

[39] E. Cha, M. D. Patel, J. Park, J. Hwang, V. Prasad, K. Cho, W. Choi, Nat. Nano. 2018, 13, 337-344.

[40] Y. Zhong, D. Chao, S. Deng, J. Zhan, R. Fang, Y. Xia, Y. Wang, X. Wang, X. Xia, J. Tu, Adv. Funct. Mater. 2018, 28, 1706391.

[41] R. Ummethala, M. Fritzsche, T. Jaumann, J. Balach, S. Oswald, R. Nowak, N. Sobczak, I. Kaban, M. H. Rümmeli, L. Giebeler, Energy Storage Mater. 2018, 10, 206-215.

[42] M. Yu, J. Ma, M. Xie, H. Song, F. Tian, S. Xu, Y. Zhou, B. Li, D. Wu, H. Qiu, R. Wang, Adv. Energy Mater. 2017, 7, 1602374.

[43] H. Pan, J. Chen, R. Cao, V. Murugesan, N. N. Rajput, K. S. Han, K. Persson, L. Estevez, M. H. Engelhard, J.-G. Zhang, K. T. Mueller, Y. Cui, Y. Shao, J. Liu, Nat. Energy 2017, 2, 813-820.

[44] W. Deng, X. Zhou, Q. Fang, Z. Liu, J. Mater. Chem. A 2017, 5, 13674-13682.

[45] C.-H. Chang, S.-H. Chung, A. Manthiram, Mater. Horiz. 2017, 4, 249-258.

[46] M. Xiang, L. Yang, Y. Zheng, J. Huang, P. Jing, H. Wu, Y. Zhang, H. Liu, J. Mater. Chem. A 2017, 5, 18020-18028.

[47] T. Chen, Z. Zhang, B. Cheng, R. Chen, Y. Hu, L. Ma, G. Zhu, J. Liu, Z. Jin, J. Am. Chem. Soc. 2017, 139, 12710-12715.

[48] X. Li, A. Lushington, Q. Sun, W. Xiao, J. Liu, B. Wang, Y. Ye, K. Nie, Y. Hu, Q. Xiao, R. Li, J. Guo, T. K. Sham, X. Sun, Nano Lett. 2016, 16, 3545-3549.

[49] Y. He, S. Wu, Q. Li, H. Zhou, Small 2019, 20, 1904332.

[50] J.-Q. Huang, X.-F. Liu, Q. Zhang, C.-M. Chen, M.-Q. Zhao, S.-M. Zhang, W. Zhu, W.-Z. Qian, F. Wei, Nano Energy 2013, 2, 314-321.

[51] X. Zhang, Y. Wei, B. Wang, M. Wang, Y. Zhang, Q. Wang, H. Wu, NanoMicro Lett. 2019, 11, 78 .

[52] D. R. Deng, F. Xue, C. D. Bai, J. Lei, R. Yuan, M. S. Zheng, Q. F. Dong, ACS Nano 2018, 12, 11120-11129.

[53] X. Wang, X. Zhao, C. Ma, Z. Yang, G. Chen, L. Wang, H. Yue, D. Zhang, Z. Sun, J. Mater. Chem. A 2020, 8, 1212-1220. 
